\title{
BACCALAUREATE COMPLETION FOR AS-T BUSINESS ADMINISTRATION STUDENTS AT SAN JOSÉ STATE UNIVERSITY
}

\author{
A Dissertation submitted to the faculty of \\ AS San Francisco State University \\ 35 In partial fulfillment of \\ 2020 \\ EDD \\ the requirements for \\ the Degree \\ .$C 37$ \\ Doctor of Education \\ In \\ Educational Leadership
}

by

Francisco Orlando Castillo

San Francisco, California

January 2020 


\section{Copyright by}

Francisco Orlando Castillo

2020 


\section{CERTIFICATION OF APPROVAL}

I certify that I have read Baccalaureate completion for AS-T Business Administration Students at San José State University Title of Culminating Experience by Francisco Orlando Castillo, and that in my opinion this work meets the criteria for approving a dissertation submitted in partial fulfillment of the requirement for the degree Doctor of Education in Educational Leadership at San Francisco State University.

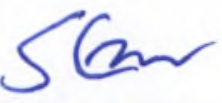

Sheldon Gen, Ph.D.

Associate Professor

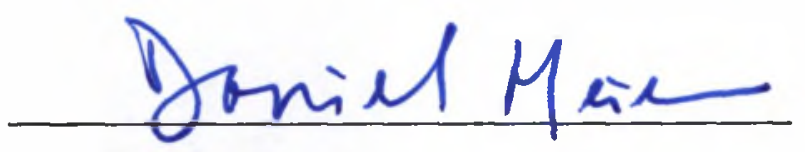

Daniel Meier, Ph.D.

Professor

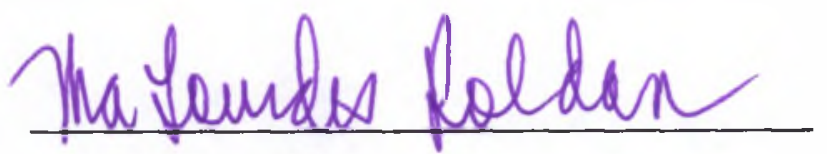

Malu Roldan, Ph.D.

Professor 


\title{
BACCALAUREATE COMPLETION FOR AS-T BUSINESS ADMINISTRATION STUDENTS AT SAN JOSÉ STATE UNIVERSITY
}

\author{
Francisco Orlando Castillo \\ San Francisco, California
}

2020

The passage of Senate Bill 1440 was meant to strengthen the pipeline from a California Community College to a California State University. This study analyzed how AS-T in Business Administration earners and non-AS-T in Business Administration earners fare at degree completion from a California State University campus. A quantitative research methodology was used to identify the effectiveness of the AS- $T$ in Business Administration program. The results of this study are mixed. Key findings indicate the preliminary benefits. AS-T earners, on average, finish their degree within 60 units at San José State University (SJSU) and earn three cumulative SJSU units fewer than their nonAS-T peers. In addition, regarding time to degree, on average, there was no statistically significant difference between Hispanic and White students, whereas historically, a gap exists between these groups. The preliminary disadvantages also include time to degree, where Asian students, on average, have a statistically significantly higher number of years to degree completion when compared to White students. These results showcase a clear discrepancy, and the need to ensure equitable outcomes at SJSU, an AsianAmerican Native American Pacific Islander Serving Institution and a Hispanic Serving Institution. Lastly, time to degree for students with an AS-T degree is greater than two years. Further research is needed to learn more about the outcomes of the AS-T program.

I certify that the Abstract is a correct representation of the content of this dissertation.

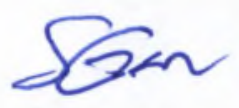

Chair, Thesis Committee

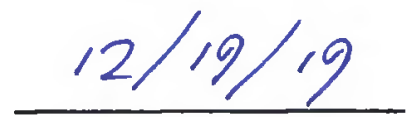

Date 


\section{ACKNOWLEDGEMENTS}

The completion of this degree requires acknowledgement of several people in my academic and professional life to whom I am grateful for their assistance with this culminating experience.

I must begin with Dr. Sheldon Gen, who chaired my committee. He offered enduring patience, constructive guidance, thoughtful encouragement and challenged me critically throughout this experience. During my time of doubt, he reminded me that I had to "make a decision to finish", as his pledge to support me was unequivocal. Dr. Gen also invited me to the inaugural Get it Done writing group, which pulled me out of a space of isolation and into a community of committed writers.

I also want to thank Dr. Daniel Meier and Dr. Malu Roldan who served on my committee. Dr. Meier provided constructive feedback on my research framework and ensured I offered a critical perspective to leadership, practice and equity. Dr. Roldan provided an analytical perspective from her experience serving as an Associate Dean of Undergraduate Program with the Lucas College of Business. She encouraged me to carefully understand my findings and continue conducting research.

Lastly, I would like to thank two colleagues, Scott Heil and Chao Vang from the Office of Institutional Effectiveness and Analytics at San José State University. They provided the data set needed to conduct this study and graciously answered numerous questions before and after I received the data. 


\section{DEDICATION}

I dedicate this work to instrumental people in my personal life whom I am grateful for their inspiration and unconditional support before and during this culminating experience.

Many years before I began my graduate experience my mother, Gloria Corvera (now Hurtado), has always been a loving and supportive parent. Her work-ethic and commitment to doing all that she possibly could for her children was truly inspirational. She always found a way and made any sacrifice needed to offer her unconditional love and support. Although your life experience did not afford you the opportunity to pursue post-secondary education, this degree is as much yours as it is mine. Mamá, te amo con todo mi corazón.

To Francisco Rodriguez Corvera, my maternal grandpa, was as a father figure to me since the sixth grade. His influence on me during my adolescent and young-adult life encouraged me to be the best man/hombre I can be and to keep going/sigue adelante. Although he passed earlier this year, his presence is always felt and his commitment to family/la familia will live on through me.

My best friend, Michael James Donohue, has been there from the beginning of this educational journey. His genuine support and encouragement have meant the world to me. Michael's optimism and positive spirit lifted me when my confidence wavered, thank you for your love and being your authentic self. Because of you, I had the unconditional love of Buddy and Simone, who always encourage me to take a break from my studies for belly rubs, a time that allowed me to process the varied emotions that surfaced during this experience.

A dear friend, Mary Streshly, Ed.D., was a fellow graduate student and carpool buddy. Our paths were unlikely to have crossed would it not have been for our graduate program. I am grateful for your encouragement and support throughout our graduate experience, but also, the last couple of years, where you consistently asked about my progress. I appreciate you! 


\section{TABLE OF CONTENTS}

List of Tables ............................................................................................................ vii

List of Appendices .................................................................................................................. viii

Chapter One: Introduction ..................................................................................................

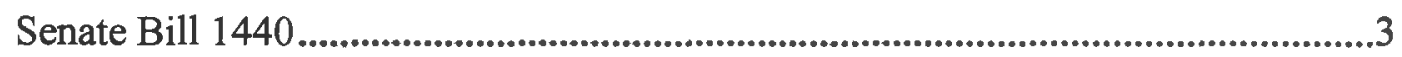

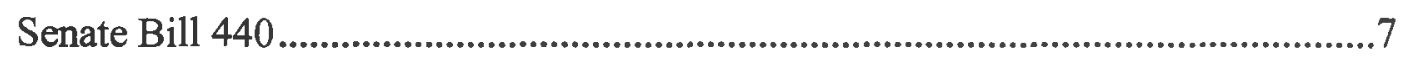

Leadership Implications........................................................................................10

Impact on Equity....................................................................................................13

San José State University (SJSU) .............................................................................14

Rationale for Proposed Study ................................................................................16

Research Questions ............................................................................................17

Research Framework ...........................................................................................20

Justification and Significance ..........................................................................................23

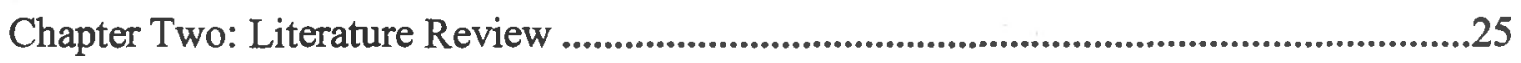

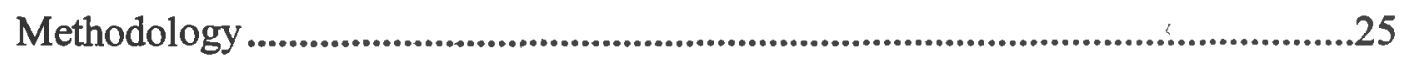

Traditional Transfer Student Pathway ........................................................................26

Associate Degree for Transfer ......................................................................................36

Traditional Associate Degree in Business Administration ......................................39

Associate of Science for Transfer in Business Administration ...............................39

Chapter Three: Methodology .......................................................................................................43

Research Design................................................................................................................43

Role of the Researcher ...................................................................................................44

Setting, Population and Sample ......................................................................................45

vii 


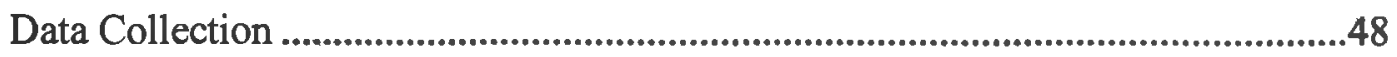

Data Analysis Procedures ..................................................................................................51

Reliability and Validity......................................................................................52

Chapter Four: Findings ..............................................................................................................54

Characteristics of the Sample...............................................................................54

Inferential Statistics ......................................................................................................58

Research question one..................................................................................58

Research question two .....................................................................................5

Research question three ...................................................................................65

Chapter Five: Conclusions and Discussion............................................................................69

Summary of Major Findings and Conclusions ............................................................69

Study Limitations and Recommendations ..............................................................73

Implications for Leadership, Practice and Equity .....................................................76

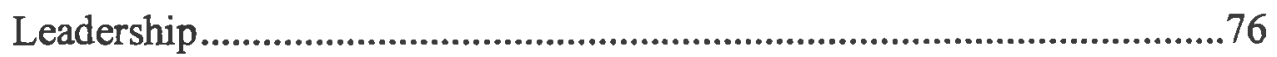

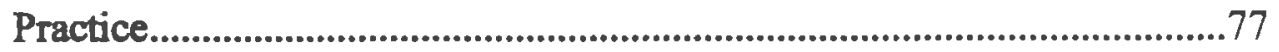

Equity .................................................................................................

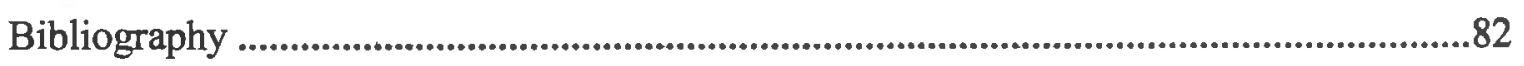




\section{LIST OF TABLES}

Table

1. Summary of Variables $49-50$

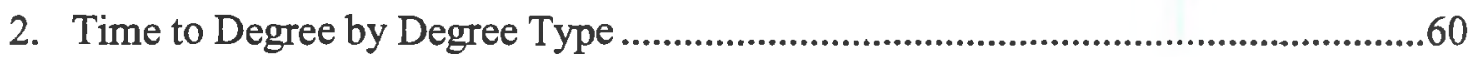

3. SJSU Cumulative Units Earned ...................................................................................61

4. Summary of Other Student Outcome Variables by Degree Type ...........................62

5. Summary of Significant Chi-Square Associations with AS-T Status Variable ......63

6. Summary of Significant Chi-Square Associations with Degree Awarded Variable

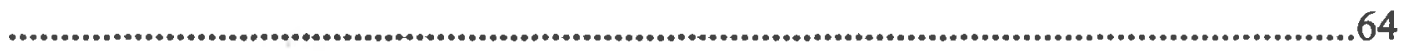

7. Time to Degree by Race and Ethnicity ...........................................................66

8. Summary of Other Student Outcome Variables by Race and Ethnicity ........... 67-68 


\section{LIST OF APPENDICES}

Appendix

Page

1. Operational Definitions 


\section{Chapter One: Introduction}

The California Community College (CCC) system has several missions. Arguably, their most important mission, the transfer mission, aims to provide foundational knowledge and prepare students, especially under-served students, to transition to a four-year institution. Annually, over 2 million students matriculate in the CCC system, the largest system of post-secondary education in the United States (California Community Colleges Chancellor's Office, 2012a). For many students in California, their only option to access postsecondary education is through the CCC (Melguizo, Hagedorn, \& Cypers, 2008). These students may know at the start of their postsecondary experience that they want to transfer to a four-year institution or decide to do so later. Either way, they need a guaranteed path to a baccalaureate degree. Unfortunately, CCC students have not had a custom curricular path to follow that fulfills lower-division general education, lower-division major requirements and admission requirements. This study will investigate the preliminary effectiveness of a transfer pathway policy in California, that aims to guide aspiring transfer students from a CCC campus to a California State University campus and prepares them for upper-division coursework with a promise and clear path to baccalaureate degree attainment.

The California Master Plan for Higher Education outlined a traditional path for CCC students to transfer to a California State University (CSU) or University of California (UC) campus and earn their baccalaureate degree. The CCC system, serves as 
an access point to postsecondary education. Unfortunately, for decades this traditional path has not proven to be highly effective. The Campaign for College Opportunity indicates the transfer rates are $23 \%$ for a six-year period (The Campaign for College Opportunity, 2016), which is very low given the long-standing establishment of the California Master Plan and the long-standing articulation agreements CCCs have with universities in both the CSU system and UC system.

The CSU system accepts and matriculates more CCC transfer students than the UC system, and does so with fewer resources. In 2010, the CSU system enrolled about 37,500 new upper-division transfers and the UC system enrolled about 15,100 upperdivision students (California Postsecondary Education Commission, 2018). Since twice as many community college students transfer to the CSU system than the UC system, the CSU has become the largest senior postsecondary education system in the state and the nation. To ensure that more Californians have a baccalaureate degree to meet the demands of the $21^{\text {st }}$ century workforce, the State of California must improve the pathway to baccalaureate degree completion for California community college students (Moore, Shulock, \& Jensen, 2009). In the early part of this decade, the State legislature passed new state policy to further support the transfer mission and establish a clear path to a baccalaureate degree for California community college students. 


\section{Senate Bill 1440}

On September 29, 2010, Senate Bill 1440, the Student Transfer Achievement Reform (STAR) Act, was signed into legislation. SB 1440 was designed to strengthen the path from a CCC to a CSU by- establishing an Associate Degree for Transfer (AD-T), which includes two degrees that align with the transfer mission: an Associate in Arts for Transfer (AA-T) and an Associate in Science for Transfer (AS-T). The intent is that aspiring transfer students would select a new AD-T over the traditional associate degrees, such as the Associate of Arts or Associate of Science.

\section{Associate degree versus associate degree for transfer.}

The traditional associate degree requires a minimum of 60 semester or 90 quarter units, a 2.0 GPA, and a set of discipline specific courses identified by local CCC faculty. These traditional degrees offer students an option to earn an associate degree prior to transfer, but the requirements for such degrees, do not guarantee overlap with core lowerdivision major coursework and CSU admission criteria. Therefore, aspiring transfer students who choose to earn a traditional associate degree prior to transfer, will need additional courses and units which may delay their transfer.

The AD-T guarantees aspiring transfer students a new opportunity. These new degrees ensure the following: a degree within 60 semester or 90 quarter units, a minimum of 18 units in a major, all courses are CSU transferable, completion of the California State University General Education - Breadth Requirements or the Intersegmental 
General Education Transfer Curriculum, fulfillment of CSU admission criteria, admission to the CSU system, and an academic plan that shows a clear path to baccalaureate degree completion within 60 semester or 90 quarter units at a CSU campus (in some cases, exceptions may apply).

The AD-T affords all aspiring transfer students the opportunity to successfully gain admissions to the CSU, not just the savviest of aspiring transfer students. The spirit of SB 1440 is to increase baccalaureate degree completion for transfer students by providing them with a new degree that aligns with the CCC transfer mission. SB 1440 declared, as a condition of state apportionment funding, all CCCs are charged with developing and offering an $\mathrm{AD}-\mathrm{T}$ in all degrees. The $\mathrm{CCC}$ leveraged their existing course identification numbering system to initiate change.

\section{Course identification numbering system.}

The CCC faculty leveraged their existing course identification numbering system (C-ID), which is designed to assign "common course numbers" to identify comparable courses within the CCC system. The CCC faculty vet these courses via the Faculty Discipline Review Groups (FDRG) and thereby, established an intrasegmental articulation. The C-ID system also offers the identification of common lower-division transfer courses from the California Community Colleges to other universities, such as the UC and CSU system. Due to improved alignment within the CCC system to support 
transfer, the Academic Senate for the California Community College, suggested the use of FDRG to establish an intersegmental curriculum development and review process.

\section{California community college changes.}

In response to SB 1440, the Academic Senate for California Community Colleges and the Academic Senate of the California State University collaborated to classify course content for the new Associate Degree for Transfer by using the C-ID system. This intersegmental approach utilized the Faculty Discipline Review Groups to offer assurance that a course tagged with the same C-ID number at different institutions are deemed comparable. Intersegmental discipline faculty utilized this infrastructure to facilitate the development and review of the Transfer Model Curriculum for the most common transfer majors. Once a Transfer Model Curriculum is finalized for a specific major, then CCC faculty may create their AD-T. For instance, on June 25, 2011, the Business

Administration Transfer Model Curriculum was finalized, which meant, $\mathrm{CCC}$ faculty and CSU faculty could work together to establish a curriculum that clearly outlined a consistent set of lower-division core courses that academically prepares aspiring transfer students for upper-division course work. The Transfer Model Curriculum was then used by the CCC to create their own AD-T, in this case, an AS-T in Business Administration that is best suited for their local CSU campus. In general, the CCC faculty use the following principles to guide their work: establish flexibility for their CCC students and ensure their $\mathrm{AD}-\mathrm{T}$ courses meet the requirements for as many $\mathrm{CSU}$ campuses as possible. Therefore, this new degree offers students the assurance they have not quite had before 
by providing them with an $\mathrm{AD}-\mathrm{T}$ that completes their first two-years of their baccalaureate degree.

\section{California state university changes.}

In response to SB 1440, the CSU underwent several changes as well.

Specifically, these changes occurred most among the division of Student Affairs and Academic Affairs. On the Student Affairs side, the Admissions office had three adjustments to make. First, CSU system-wide, the CSU central application system CalState Apply (formerly known as CSU Mentor) now asked the following question: which of the following best describes your current educational status? Any student that selected the response Transferring with an Associate Degree for Transfer (AA-T/AS-T) awarded by a California Community College, essentially self-reported they planned to complete such degree by the end of the Spring semester, prior to Fall matriculation at a CSU campus. Students who selected such response, were also required to select a specific California Community College and the appropriate AD-T program. Third, each CSU campus Admission's Office, now had to verify such self-reported information, per an official transcript the applicant is required to submit from the CCC they specified to the CSU campus they plan to attend in the Fall.

On the Academic Affairs side, academic Colleges across the CSU system had faculty and/or staff involvement in the development of $\mathrm{AD}$ - $\mathrm{T}$ for selected baccalaureate degrees. CSU campuses prioritized the most common programs selected by aspiring 
transfer students. Faculty from various programs were then charged to develop a twoyear curriculum that includes all remaining baccalaureate degree requirements without exceeding the 60-unit limit (in some cases, exceptions may apply). The two-year curriculum outlines the courses and requirements students need to complete each semester over a two-year period, offering students a clear path to baccalaureate degree completion.

\section{Senate Bill 440}

On October 10, 2013, Senate Bill 440 expanded on the SB 1440 act. The act includes four amendments. First, each community college would be required to offer an AD-T for every program or area of emphasis in each "traditional" associate degree they offered prior to the 2013-14 academic year with an approved transfer model curriculum. The act required this implementation before the start of the 2015-16 academic year. This change aims to leverage transfer model curriculums already developed and require community colleges to develop and offer more AD-T degrees to their students. Second, each CSU campus would be required to accept the transfer model curriculum-aligned $\mathrm{AD}-\mathrm{T}$ in every major and concentration offered at the CSU. This enhancement directs attention to the lack of access to all degrees offered at the CSU. For example, an approved transfer model curriculum-aligned AS-T in computer science may exist at a community college, but may not have an approved AS-T in computer science at a local CSU campus. Thus, a student would not have the benefit of a clear pathway to complete a computer science degree. An alternative would be that a CSU campus could accept 
such student to a similar degree, granted the CSU campus had a similar degree. Third, the act required the CSU to develop an admissions redirection process for $\mathrm{AD}-\mathrm{T}$ applicants. That is, if a student with an $\mathrm{AD}-\mathrm{T}$ were denied to a CSU campus due to impaction (i.e. student did not meet the GPA threshold), the student would be redirected to another CSU campus, even if they did not apply to that specific CSU campus. Lastly, the act required the development of a student-centered communication and marketing strategy to promote the $\mathrm{AD}-\mathrm{T}$ as the preferred transfer pathway. This modification aims to enhance communication to aspiring transfer students at the following junctions: outreach to high school students, new student orientation, first-year community college students, and prominent visual displays in counseling and transfer centers promoting the benefits of the $\mathrm{AD}-\mathrm{T}$.

\section{Progress update.}

A few years after the passage of SB 1440, evidence shows the CCCs began swift implementation. The Legislative Analyst Office revealed, that in Fall 2013, about 11 percent of all associate degree graduates earned an AD-T and about 200 graduated with a baccalaureate degree from the CSU (Taylor, 2015). In Fall 2014, about 7,000 AD-T students enrolled in the CSU (Taylor, 2015), which suggests, about 38 percent of $\mathrm{AD}-\mathrm{T}$ earners transferred to a CSU (The Campaign for College Opportunity, 2016). Although, more and more associate degree earners are choosing to earn an $\mathrm{AD}-\mathrm{T}$, the annual transfer admits in the CSU is more than 50,000 (Taylor, 2015). There is a need for more targeted marketing, communication, and academic counseling to inform prospective 
transfer students of the existing AD-T options. In addition, not all associate degrees have an $\mathrm{AD}-\mathrm{T}$ option, so the number of $\mathrm{AD}-\mathrm{T}$ programs also need to increase, wherever possible.

In early 2015, the CCC and CSU had jointly developed 33 "transfer model curricula" to develop more AA-T and AS-T degrees. These efforts reached about 80 percent of majors that transfer students select (Taylor, 2015). When examining the AS-T degrees only, Business Administration, Administration of Justice, and Early Childhood Education, make up $87 \%$ of all AS-T degrees awarded, leaving $13 \%$ to traditional Science, Technology, Engineering and Mathematics (STEM) degrees (The Campaign for College Opportunity, 2016). Since Business Administration is one of three popular AS-T programs, further investigation was needed to determine how popular this degree was CSU system-wide. After review of all degrees earned in the CSU system, the baccalaureate degree in business is the most popular. In Fall 2015, over 18,000 CSU graduates earned an undergraduate degree in business, by far the most popular undergraduate degree (California State University, 2018). To some, this may be no surprise, since California is the $5^{\text {th }}$ largest economy in the world with booming businesses in technology, agriculture and entertainment. An opportunity to learn how AS-T business administration earners and non-AS-T business administration earners fare at degree completion from a CSU campus could showcase early implementation progress on this important social justice initiative and potentially provide an opportunity to learn how to 
strengthen the pipeline from the CCC to the CSU for students interested in business administration.

\section{Leadership Implications}

Senate Bill 1440 (2010) and 440 (2013), are statutes designed to keep the promise of baccalaureate degree attainment for students that begin post-secondary education at their local CCC. By selecting the most affordable route to a four-year degree, aspiring transfer students put their trust in the California Master Plan. The need to strengthen the transfer mission is growing and arguably becoming more important than ever before for several reasons.

First, the CCC have garnered support from the state legislature to provide free tuition for the first and second years of college through the College Promise Program at participating CCCs. Eligibility requirements include the following: first-time students, full-time enrollment and California residents or AB 540 students. This new opportunity will likely draw CSU admits to their local community college to complete their lowerdivision major and General Education requirements in two-years in preparation for transfer. This new educational opportunity could lead to more transfer students in the future. In addition, $\mathrm{CCC}$ have always been an entry-point to post-secondary education for returning adult students. These students often have multiple responsibilities, such as work and family commitments, and therefore are likely to enroll part-time. As the need 
for a more educated workforce continues to rise, the $\mathrm{CCC}$ will need to sustain and strengthen their partnership with the CSU.

Second, a partnership between the two largest post-secondary education systems in the nation is essential for baccalaureate degree completion in California. The AD-T program provides students with a clear pathway to a baccalaureate degree. Since the establishment of TMCs, each year, more students earn an AD-T degree. In the years to come, this degree will be the preferred option as the most efficient option to earn an associate degree, transfer, and earn a baccalaureate degree from a CSU. To ensure these outcomes, the current approach used for intrasegmental and intersegmental collaboration will need to continue. That is, the Academic Senate for California Community Colleges and the Academic Senate for California State University will need to sustain the communication and collaboration among faculty from both systems by discipline - all major actors that help with implementation (Fowler, 2013). Communication and collaboration are critical to ensure that changes to discipline specific curriculum and relevant courses that overlap with the AD-T program are kept current to ensure student success.

Third, support for articulation officers at both the CCC and the CSU will be essential to sustain and the enhance the capacity required to efficiently implement Senate Bill 1440 (2010) and 440 (2013). Adequate resources are needed to ensure that efforts to create the $\mathrm{AD}-\mathrm{T}$ program translate into a seamless articulation and accurate student 
records. Articulation officers are currently the lead point person and play a key role in communication and coordination to key and varied constituents at their respective CCC or CSU campus. The Department Chair or Associate Dean of academic colleges are an important constituent that need to be involved to facilitate timely communication to faculty regarding curricular changes. Admissions and Records personnel are vital for verification of AD-T programs. Each CCC and CSU campus utilizes a student information system, and such systems need to utilize efficient procedures so that students and academic counselors or academic advisors have access to AD-T program verification. Access to such information will ensure that $\mathrm{AD}-\mathrm{T}$ students receive accurate and timely support. In addition, many student information systems utilize a degree audit function to showcase to students their progress toward a degree. Thus, Degree Audit Analysts should be kept abreast, so that degree audits accurately reflect a path to graduation for verified $\mathrm{AD}-\mathrm{T}$ students.

Lastly, Senate Bill 1440 (2010) and 440 (2013) are essentially equity-focused statues that resulted from the need to improve transfer from one public system, the CCC, which offers lower-division college course work to a diverse student population, and another, the CSU, which offers upper-division college course work to a diverse student population as well. The two systems are working together to address a specific problem, improve the transfer mission and baccalaureate degree completion for a more educated and diverse workforce in California. 


\section{Impact on Equity}

The CCCs are meant to provide access to baccalaureate education, by allowing students to complete lower-division courses at a lower cost to both students and the state (Moore et al., 2009). If their path to a CSU does not end with a baccalaureate degree, then we fall short of the California Master Plan and the opportunity for a more educated workforce. Current trends indicate the state of California will have one million fewer college graduates than are needed. The lack of basic skills necessary to participate in a democratic society, will keep low-income, first-generation, and students of color in lowwage jobs (Bahr, 2008) and the average educational degree in California's workforce will remain low (Offenstein \& Shulock, 2009).

Furthermore, the lack of educational attainment also reduces the opportunity to advance from the lower-income strata to a higher socioeconomic status (Bailey \& Morest, 2006), replicating the socio-economic stratification where low-performing schools prepare students for low-skilled jobs, which lead to low-wages, and ultimately keeps these students in the low-income strata. Educational attainment has long been considered an equalizer of life's opportunities - a powerful predicator of socioeconomic outcomes - but for students without postsecondary education, the ability to participate in a highly technical workforce without a degree will be very challenging (Warren, Hauser \& Sheridan, 2002). 
In California, many low-income, first-generation, and students of color begin their path toward a baccalaureate degree at their local community college (Hagedorn \& Cepeda, 2004). One study estimates that $69 \%$ of Latinos and $65 \%$ of African Americans, compared to $60 \%$ of White and $42 \%$ of Asian American students, enter postsecondary education at a community college (Gandara, Alvarado, Driscoll, \& Orfield, 2012). As California's population continues to diversify, the need to strengthen the transfer pathway and baccalaureate degree completion for low-income, first-generation, and students of color, also continues to be critically important. By 2025, the state's population will continue to change, as $42 \%$ will be Latino, $35 \%$ will be White and immigration from Asia will continue to increase, as it has over the past decade (Johnson \& Hill, 2015). The shift in demographics in California signals that most future college students will come from historically underserved communities - low income, first in their families to attend college, and ethnic groups such as Latinos, African Americans and Southeast Asians. Since many students from these communities begin postsecondary education at a California community college, it's important to learn more about students who transfer to their local CSU campus. Increasing equity and diversity is critical and an opportunity to learn more about the Associate Degree for Transfer at a single and racial/ethnic diverse CSU campus would help us learn more about its preliminary impact.

\section{San José State University (SJSU)}

SJSU is a comprehensive state university located on the west coast with a high undergraduate profile. This institution is part of the California State University System 
(CSU). The university is designated as an Asian American Native American Pacific Islander Serving Institution (AANAPISI) and a Hispanic-Serving Institution (HSI). The student population is different than predominantly White institutions (the setting for most research on vertical transfer students), not only by race and ethnicity, but socio-economic status. Many SJSU students receive federal and state financial aid to fund their education. In addition, over $50 \%$ of the student population is comprised of transfer students, of which, many have transferred from a CCC (San José State University, 2018a).

For the past five academic years, the Lucas College of Business had the university's largest undergraduate student population with about 5,000 to 5,500 students enrolled annually, many of which are transfer students from a CCC. Over the past few years, the two-year graduation rates for transfer admits majoring in Business Administration have been low. From Fall 2011 to Fall 2015, the two-year graduation rates have only increased $4 \%$, from about $18 \%$ to $22 \%$, respectively (San José State University, 2018b). In addition, there was a minimal increase of $3 \%$ among students who earned $30+$ SJSU units at the end of their first-year, from about $8 \%$ to $11 \%$, respectively. When comparing the 2-year graduation rate from the Fall 2015 cohort to the Fall 2016 cohort, there was a $10 \%$ spike, from about $22 \%$ to $32 \%$, respectively. In addition, there was an increase of $10 \%$ among students who earned $30+$ SJSU units at the end of their first-year, from about $11 \%$ to $21 \%$, respectively. This increase in degree completion for transfer students supported the interest to begin this study. 


\section{Rationale for Proposed Study}

This study will focus on transfer students earning a baccalaureate degree in business administration and will contribute to the conversation on transfer student outcomes from a racially and ethnically diverse campus, of which, there is a need for research. In addition, this study will investigate educational equity issues that may manifest in degree completion outcomes for AS-T in business administration students and aims to showcase preliminary policy effectiveness.

More specifically, the purpose of this study is to shed light on how AS-T business administration earners and non-AS-T business administration earners fare at degree completion from SJSU, a CSU campus. As of Fall 2015, there were seven of the thirteen concentrations with an AS-T in business administration at SJSU. Since SJSU awards more undergraduate business degrees than all but one CSU campus, learning more about this student population would contribute to further understanding of the preliminary impact of the AS-T initiative at one CSU campus. A case-study approach would provide an opportunity for in-depth understanding of their experience at a receiving institution. The findings could have potential significance to local CCC feeder schools, the Lucas College of Business and SJSU. For instance, the outcomes could be shared with local CCC students and counselors to promote the AS- $\mathrm{T}$ in business administration program and be used to encourage aspiring students to pursue this curriculum to ensure baccalaureate degree completion in a timely manner. As more community colleges begin to offer free tuition for the first two years of college, the Lucas College of Business will 
need to showcase how all students are achieving success as measured by timely degree completion. As a large and urban CSU campus, SJSU could be a destination of choice for aspiring transfer students, especially for historically under-served students who accessed postsecondary education from a $\mathrm{CCC}$ with the goal of obtaining a baccalaureate degree at their local CSU campus.

\section{Research Questions}

A quantitative approach will provide preliminary insight to the effectiveness of the AS-T in business administration program. By focusing on numerical data, statistical analysis will be performed to examine statistical differences between two groups, three or more groups and relationships between categorical variables per the research questions for this study.

1) Do AS-T in business administration earners finish their degree within two-years of transfer?

$$
\mathrm{H}_{0}: \mu_{\text {non-AS-T }}>\text { two-years. The non-AS-T business administration earners will }
$$
earn their baccalaureate degree in business administration in more than two-years after transfer.

$\mathrm{H}_{\mathrm{a}}: \mu_{\mathrm{AS}-\mathrm{T}} \leq$ two-years. The AS-T business administration earners will earn their baccalaureate degree in business administration in less than or equal to two-years after transfer. 
2) How do AS-T business administration earners compare to non-AS-T business administration earners at finishing their degree? If the AS-T program meets the desired program outcome, then AS-T earners will earn their baccalaureate degree in less time and within 60 units earned a SJSU than non-AS-T earners.

$\mathrm{H}_{0}: \mu_{\text {AS-T }}-\mu_{\text {non-AS-T }} \geq 0$. The AS-T in business administration earners will earn their baccalaureate degree in business administration in the same amount of time (years/number of terms) or in more time than the non-AS-T in business administration earners.

$\mathrm{H}_{\mathrm{a}}: \mu_{\mathrm{AS}-\mathrm{T}}-\mu_{\text {non-AS-T }}<0$. The AS-T in business administration earners will earn their baccalaureate degree in business administration in less time (years/number of terms).

$\mathrm{H}_{0}: \mu_{\text {AS-T }}-\mu_{\text {non-AS-T }} \geq 0$. The AS-T in business administration earners will earn their baccalaureate degree in business administration with 60 or more units earned at SJSU than non-AS-T in business administration eamers.

$\mathrm{H}_{\mathrm{a}}: \mu_{\mathrm{AS}-\mathrm{T}}-\mu_{\text {non-AS-T }}<0$. The AS-T in business administration earners will earn their baccalaureate degree in business administration more efficiently by earning fewer units at SJSU.

3) Are there significant differences in baccalaureate degree completion between URM and non-URM students who transfer with an AS-T in business administration? 
$\mathrm{H}_{0}: \mu$ URM $-\mu_{\text {non-URM }} \geq 0$. The URM students who transfer with an AS-T in business administration will earn their baccalaureate degree in business administration within the same amount of time (years/number of terms) or more time than their nonURM peers.

$\mathrm{H}_{\mathrm{a}}: \mu_{\text {URM }}-\mu_{\text {non-URM }}<0$. The URM students who transfer with an AS-T in business administration will earn their baccalaureate degree in business administration in less time (years/number of terms).

It is expected that students who complete their degree in two years earn at least 15 units per semester or a total of 30 units per academic year (Fall, Winter, Spring and Summer terms). Transfer students who earn an AS-T have completed lower-division general education and lower-division major requirements, therefore they only need upper-division general education and upper-division major requirements to complete their degree. These AS-T earners have a clear path to graduation as sample academic plans outline their remaining 60 units and are available online on an SJSU website. In addition, transfer students working less than 15 hours per week may be able to manage a 15-unit course load per term.

Non-AS-T earners may not have completed their lower-division general education and lower-division major requirements; thus, they may have more than 60 units to complete and possibly delay their graduation beyond two-years post-transfer. These students may lack a clear path to graduation and may be unsure which degree 
requirements remain, creating the opportunity to make uninformed decisions. In addition, students who work more than 15 hours per week, may not earn 15 units per semester or 30 units per academic year.

\section{Research Framework}

The framework used in this applied research study is linked to the research questions this study aims to answer. The framework includes three components. The first is the $\mathrm{AD}-\mathrm{T}$ program theory, followed by a critical policy analysis perspective and critical race theory. Next, the components of the framework are described in further detail and how each component will be used to help interpret the research findings.

The $\mathrm{AD}-\mathrm{T}$ program theory is described next to illustrate the desired program outcome. In general, if a transfer student completes an $\mathrm{AD}-\mathrm{T}$ from a $\mathrm{CCC}$ and they apply for admissions to a CSU campus, then we expect them to graduate from a CSU campus in two-years or within 60 units earned at the CSU campus. In other words, a transfer student with an AD-T may only be held to no more than 60 units by the CSU campus. The $\mathrm{AD}-\mathrm{T}$ program provides a clear pathway to complete the remaining requirements to attain a baccalaureate degree. The pathway is showcased in the form of a roadmap, which shows four academic terms and the recommended courses a student should take each term. Each term has a total of 15 units, which is equivalent to five courses. The total number of units the student is expected to earn at their respective CSU is no more than 60 units. If the student; takes the recommended courses, completes 15 units each 
semester, and completes the appropriate course sequence (when applicable), with the appropriate grade minimums, then the student will have their degree conferred by the Office of the Registrar. Once their degree is conferred a graduation term is identified, which allows the researcher to measure the outcome variables for research question one and two. This program theory describes the rationale for a quantitative approach and the lens in which research questions one and two are examined.

The second component of the framework links to policy analysis. More specifically, a critical policy analysis is essential for this study because SB 1440 (2010) and 440 (2013) identified a critical problem: many low-income, first-generation, and students of color begin their postsecondary experience at a community college, but among these students with aspirations of transferring to a four-year university and actually completing a baccalaureate degree, their completion rate is low (Dougherty, 1992; Dougherty \& Kienzl, 2006). This study will examine which students benefit from the $\mathrm{AD}-\mathrm{T}$ in business administration, who does not benefit, and are there significant differences in baccalaureate degree completion between URM and non-URM students (Marshall, 1997). Young (1999), emphasizes the value in using critical policy analysis to assess impact of a policy on students based on race, class, and gender, given the stratification in the United States and higher education. For this study, the examination of SB 1440 (2010) and 440 (2013), specifically the preliminary outcomes of the AS-T in business administration at SJSU is essentially an opportunity to advance social justice policy and implementation as it relates to the post-secondary education outcome - 
baccalaureate degree completion at a CSU campus. The investigation will examine race and class, as these characteristics are prevalent in the literature review conducted. Whereas gender was not as prevalent, outside of the area of STEM education, and therefore not within the purview of this study.

The third component of the framework links to critical race theory (CRT). Unfortunately, racial inequities in education continue to persist in the United States and CRT has been used to analyze and critique policies and practice in education (LadsonBillings, 2005). As mentioned before, the California Master Plan outlined a path to access higher education from a CCC and offers hope for baccalaureate degree attainment. Many students of color and those from low-income families begin their collegiate experience at a CCC. Gandara, Alvarado, Driscoll, and Orfield (2012), estimate that 69\% of Latinos and $65 \%$ of African Americans begin their undergraduate experience at a CCC. However, Crisp and Nuñez (2014), found a transfer racial gap between URM and White students, where only $31 \%$ of Latino and African American students transferred, compared to $45 \%$ of White students. Informed by these research findings, this study will include both a binary comparison of URM and White students, and disaggregation by each racial/ethnic group to examine transfer student outcomes. The need to use CRT as a tool to examine the educational outcomes of the AS-T in business administration, as it pertains to race/ethnicity, is important to identify if equity is actualized in this new educational policy. 
As a collective, the components of this research framework will serve as the analytic underpinnings for this study.

\section{Justification and Significance}

This research study may provide insight on the progress students have made with the implementation of the AS-T in business administration. There is little research conducted that focuses on California community college student's baccalaureate degree completion as an upper-division transfer student to San José State University via an AS-T degree pathway. Since the AS-T in business administration is in the early phase of implementation, this study could showcase early effects of the transfer student path toward baccalaureate degree completion and inform educational practice or policy. Although this may seem like an ambitious task, it is important to attempt to investigate and learn, as we continue our pursuit of achieving equity.

Most of the studies cited in the literature review include types of institutions that are research-focused versus teaching-focused and pre-dominantly white institutions versus racial/ethnic diverse institutions, such as SJSU which is both an Asian American, Native American, Pacific Islander - Serving Institution and a Hispanic - Serving Institution. In which case, this study provides an opportunity to investigate early outcomes of a transfer pathway policy and highlight possible educational equity issues or offer improvements to address equity issues, even if the policy did not explicitly include an equity component. In addition, this study may showcase the need for leadership 
change, organizational change or the like, to improve the $\mathrm{AD}-\mathrm{T}$ policy, so that we may advance opportunity through equity in education. 


\section{Chapter Two: Literature Review}

The focus of this study is to learn how California community college transfers who earn an AS-T compare to non-AS-T earners at baccalaureate degree completion. The purpose of this literature review is to exhibit the literature that informed this research project. This chapter will begin with an overview of the methodology used to review relevant literature. Next, a comprehensive presentation of relevant literature begins with the traditional transfer student pathway, followed by the Associate Degree for Transfer legislation. Lastly, the traditional Associate Degree in Business Administration and the new Associate Degree for Transfer in Business Administration are presented.

\section{Methodology}

The strategy used to identify empirical research began with the following key word searches: community college, community college transfers, California community college, California community college transfers, transfer(s), college persistence, completion, baccalaureate attainment, academic persistence, transfer students, transfer baccalaureate attainment, transfer policy, community college access, community college transfer mission and transitional experiences. The indexes used to access relevant peer reviewed studies included EBSCO Academic Search Complete, EBSCO Education Full Text, EBSCO Education Research Complete and ProQuest. In general, the following criteria were used to select literature for the review or to guide the review: peer-reviewed articles, academic indexes, and studies completed in the past decade, except for seminal 
work. The seminal work cited in this chapter was consistently cited throughout the review of relevant literature. These influential studies highlighted key findings that provided guidance to this study. The seminal work combined with current research displayed the various topics that urge further investigation.

When searching for literature on a key construct such as the Associate Degree for Transfer, the traditional indexes did not offer peer reviewed studies. Therefore, a search was conducted on the California Community College Chancellor's Office website and the California State University Chancellor's Office website. Lastly, a search for relevant educational policy included searching publications and reports from the Legislative Analyst's Office, Postsecondary Education Commission, the Public Policy Institute of California and the like. This literature review exposes the scholarship that paved the way for this study. The findings of this literature review are presented next.

\section{Traditional Transfer Student Pathway}

This section of the literature review will outline relevant literature on the traditional transfer student pathway - from a community college to a four-year university or college. First, an operational description of a transfer student will be disclosed. Second, an explanation why the path from a community college to a four-year university is a desired point of entry for so many students. Third, is a national perspective on the challenges community college students face to complete the transfer mission. Lastly, an 
overview of the hurdles successful transfer students faced at the receiving institution to achieve baccalaureate degree attainment.

\section{Transfer student defined.}

There are various definitions of transfer students in the literature. Adelman (2005) defined in a study using multiple national data sets, that successful transfer students are those who a) start at a community college b) earned more than 10-degree applicable units c) attend a four-year institution and d) subsequently earn more than 10 credits from a four-year institution. However, this is not the only transfer student definition. There are various definitions used to describe transfer students. Some transfer students are defined as "reverse" transfer students, those that begin at a four-year university and transfer to a community college (Townsend, 2001). Other transfer students begin at one four-year university and transfer to another four-year university, horizontal transfer. Students who attend a four-year university during regular session (fall or spring) but choose to enroll at a community college during the intersession (winter or summer), may be considered transfer students as well. Lastly, the longstanding path for students who start at a community college and transfer to a four-year institution is considered a vertical transfer (Townsend, 2001).

The vertical transfer pathway aims to support baccalaureate degree completion for undergraduates that begin post-secondary education at the community college. A national study by Hossler et al. (2012) brings to light the transfer and mobility patterns of 
students that began college in fall of 2006 , across all postsecondary institutions, over a span of five years. This study found that among the students whose initial transfer destination was from a two-year institution to four-year institution, over 60 percent of students transferred from a public two-year institution to a public four-year institution. In addition, close to 80 percent of students who started at a public two-year institution transferred within state. The limitations of this study are twofold. First, their primary focus is on the first transfer destination. Second, the study focused only on pre-degree transfer and mobility, that is, students that transferred from a two-year to a four-year institution without earning an Associate's degree. Another study by Shapiro et al. (2017), focused on students who began their undergraduate education in the fall of 2010 at a community college and moved vertically to a four-year institution with or without receiving a credential (either a certificate or associate degree). This nation-wide study found that 31.5 percent transferred within a six years span. Among these vertical transfers, 34 percent earned a credential before transfer. The researchers also found that student transfer rates were higher for colleges that award proportionally more occupational credentials, than colleges that award more academic degrees, 33.2 percent vs. 29.9 percent, respectively.

This study will focus on the vertical transfer from a public two-year community college in California to a four-year public California State University campus and provide preliminary outcomes for students who earned an Associate credential customized for aspiring transfers. 


\section{Starting at a California community college.}

The California community college (CCC) has an important role in the California postsecondary education system. Their open admissions policy offers many students access to postsecondary studies. In the fall of 2017, the enrollment total was $1,595,006$, while first-time students reached 272,402 and continuing students soared at 900,159 (California Community Colleges Chancellor's Office, 2018a). The CCCs have several commitments to students in their mission statement. One commitment is to support and prepare students to transfer to a higher-level of post-secondary education. For these students, California community colleges serve as a point of entry to post-secondary education and access to four-year postsecondary institutions.

There are many reasons why students decide to begin their postsecondary education at CCC. For many students the community college is the most affordable option for them. California has one of the lowest student fees in the country at $\$ 46$ per unit (CCCCO, 2018b). In addition, students may utilize Federal and State aid programs, grants and scholarships leaving them with the option to complete their first two years of college with little to no debt (CCCCO, 2018c). Students may also live at home while completing their first two-years of baccalaureate credit, which reduces their cost of attendance and overall cost of a postsecondary education. The CCCs offer high-quality education at a lower expense which provides access to social and economic mobility for poor or low-income students. The CCC is also where many racial/ethnic diverse students begin postsecondary education. 
The CCC serve many students of color, of which, the majority are first in their family to pursue a baccalaureate degree. For the 2016-2017 academic year (California Community Colleges Chancellor's Office, 2019b), the ethnic background of these students consisted of 145,697 (6.13\%) African-American, 10,272 (0.43\%) American Indian, 274,389 (11.54\%) Asian, 67,514 (2.84\%) Filipino, 1,036,647 (43.58\%) Hispanic, 87,487 (3.68\%) Multi-Ethnicity, 9,810 (0.41\%) Pacific Islander, 118,533 (4.98\%) Unknown, and $628,324(26.41 \%)$ White. Although, the CCC serve a diverse racial/ethnic study body, assisting these students in attaining their goal of transferring to a four-year institution garnered lower than desirable outcomes. Several studies have exposed the disproportionate impact low transfer rates have on students of color and those from lowincome families (Hagedorn, Moon, Cypers, Maxwell \& Lester, 2006; Rendon \& Valdez, 1993). The need to help achieve equity and social justice for underserved students is still needed today.

The CCCs continue to work toward achieving educational equity and do so by helping aspiring transfer students prepare for upper-division coursework at a four-year institution. The CCCs provide students with an opportunity to complete lower-division college-level course work. This would include lower-division major requirements and a general education curriculum offered at their local community college. Students undecided on a major or career may explore their major or career options before transferring to a four-year institution. 
Lastly, high school graduates may need to enhance their secondary academic preparation in English and mathematics, before or while they complete the lower-division major requirements and the general education transfer curriculum. Since CCCS have no admission requirements, the transfer mission, essentially offers an opportunity for students without four-year college preparation from high school an opportunity to pursue a baccalaureate degree. While the CCCs offer students access to post-secondary education, there are some challenges students face to complete the transfer mission and do so in a timely manner.

\section{Challenges of completing the transfer mission nation-wide.}

Unfortunately, access to a four-year institution from a community college is an education pathway few students experience. One study (Melguizo, Kienzl, \& Alfonso, 2011) used a National Educational Longitudinal Study (NELS) from 1988, a nationally representative sample of eighth graders, and found that only a small percentage of students complete the transfer mission. A recent study (Horn, 2009) found that 19 percent of students beginning their post-secondary education experience at a community college transferred within three years of initial matriculation. Among these students, 11 percent successfully transferred to a four-year university and eight percent transferred to another two-year institution. Transferring from a community college to a four-year university presents many barriers for community college students with aspirations of earning a baccalaureate degree. 
One barrier students encounter is the CCCS lack adequate academic preparation. Research illustrates, about $15 \%$ of students are ready for transfer level mathematics and about $28 \%$ are ready for transfer level English (California Community Colleges Chancellor's Office, 2012a, 2012b; Murray, 2008). Many students are placed below college-level course work, which can lead to one or more courses prior to reaching transfer level course work in English or mathematics.

A second barrier is the inability to finance their post-secondary education, that is, pay for the cost of attendance. Community college students are often from low-income families and select to enroll in community colleges because of their low cost of tuition (Chavez, 2008; Gandara, et al., 2012). However, these students still struggle to pay for books and supplies, transportation, and rent, (Chavez, 2008), so being employed full-time or part-time while enrolled in college is not uncommon.

A third barrier is the lack of institutional commitment to help community college students fulfill their transfer aspirations. Ornelas and Solorzano (2004) found at one large $\mathrm{CCC}$ the institution lacked transfer information and a commitment to fulfill the transfer function. When many CCC students are first in their family to attend college, their reliance on institutional agents such as academic counselors are critical. However, there are not enough counselors for students to meet with for one-on-one appointments to discuss their transfer aspirations. Hagedorn, et al. (2006), identified that counseling is key to supporting students' progress through the community college experience to 
transfer, but when student to academic counselor ratios are 1000:1, students with transfer aspirations have limited access to a critical institutional support.

Lastly, baccalaureate-aspiring students do not have a transfer curriculum to follow. Adelman (2005) indicates when community college students have too many options, it leads to confusion and uncertainty. That is, a student could be interested in pursuing a baccalaureate degree program at few a UC campuses and CSU campuses, but the requirements for such program may differ from campus to campus within a system and between systems, leaving an aspiring transfer student without a clear path. For students who navigate the transfer process successfully, they may also experience challenges at the receiving institution.

\section{Challenges at the receiving four-year institution.}

Transfer students may encounter several challenges at the receiving four-year university. Several studies at single institutions, typically four-year research-intensive universities, found that one challenge involved academic performance. Hills (1965), identified that some students experience "transfer shock", a dip in GPA. Later studies found the dip in GPA was in their major area of study (Glass \& Harrington, 2002), and the dip in GPA was minimal (Townsend \& Wilson, 2009).

Aside from academic performance, Laanan $(1996,2007)$ found transfer students may also struggle with the environmental and institutional culture at the four-year institution. However, Kirk-Kuwayne and KirK-Kuwayne (2007), found that transfers 
from a community college adjusted to their new institution, better than transfers from another four-year institution.

Lastly, transfer students may lose course credits when moving from one institution to another institution. In general, from a national perspective, transfer students can lose, on average, 13 credits when transferring institutions (Simone, 2014). The average amount of credits lost varies by type of transfer (Simone, 2014). Those students that transfer vertically, from a public two-year institution to a public four-year institution, on average, lose nearly eight credits; the lowest number of credits lost among all transfer types (Simone, 2014). Monaghan and Attewell (2015) found that the loss of credits from a community college to a four-year university is one possible reason why community college transfers are less likely to complete a four-year degree, in comparison to the native freshmen admits who begin their post-secondary education at a four-year institution. In addition, Doyle (2006) found among transfer students who had all their credits accepted, 82 percent graduated within six years with a bachelor's degree, compared to 42 percent that lost some credit. Doyle (2006) argues the loss of credits are the responsibility of state-level and institutional policymakers, and the articulation agreements, course numbering system and curriculum decisions they create, play a critical role on the number of transfer credits accepted and therefore, the likelihood of baccalaureate degree attainment. 
The mobility and acceptance of transfer credits are vital for baccalaureate degree completion. The nuance of credit applicability has also been an area of interest for research. Kadlec and Gupta (2014), revealed from a qualitative study, that transfer students loss program degree credit they expected to apply to their major, to excess elective units. To illustrate, the relevance of this research to this study, student transfers may lose the college credits earned at one institution (community college) as the college credit may not be applied in a manner most beneficial to the student by the receiving institution (four-year institution - CSU campus). That is, credit earned at a community college, may be considered CSU transferable-credit, acceptable for college-level unit credit at any CSU campus, but such course may or may not be acceptable for the student's major requirement(s), but rather elective credit to meet the minimum units (120) required to earn a baccalaureate degree. Some states, like Texas and California have focused on articulation agreements to help reduce the loss of college credits. Hodara, Martinez-Wenzl, Stevens, and Mazzeo (2016), conducted a 10-state qualitative study on the varied policy approaches to credit mobility and identified that credit mobility policies, which they refer to as transfer pathway policies, have two primary features. One, credit applicability is where course credit can serve in lieu of a major requirement at the receiving institution. Second, major-ready status is when students achieved upper-division standing by completion of lower-division general education, and all pre-major requirements for a program of study. Hodara et al. (2016) included California's (UC and CSU) policies in their study and recommended ongoing evaluation 
of transfer policy effectiveness. The subsequent section will outline California's attempt to facilitate transfer from a CCC campus to a CSU campus.

California has taken another step forward to support baccalaureate degree completion by passing new policy. In September 2010, the Student Transfer Achievement Reform Act (commonly referred to as SB 1440 - Padilla) was signed into legislation to establish a more formal partnership with the $\mathrm{CCC}$ system and the CSU system by establishing the Associate Degree for Transfer.

\section{Associate Degree for Transfer}

This section of the literature review will provide the details of the Associate Degree for Transfer (AD-T) at a California community college such as, the program requirements and benefits, as well as the two types of programs. In addition, the benefits and nuances of the $\mathrm{AD}-\mathrm{T}$ at the receiving California State University are revealed.

\section{California community college.}

In the last several years, the $\mathrm{AD}-\mathrm{T}$ was created to offer prospective transfer students a clear path to prepare for transfer at a California Community College with the goal of completing a baccalaureate degree within 120 units from a California State University campus. In order to earn an $\mathrm{AD}-\mathrm{T}$, baccalaureate-aspiring students at a $\mathrm{CCC}$ are required to a) complete one of two transfer general education patterns, the Intersegmental General Education Transfer Curriculum or the California State University General Education - Breadth Requirements; b) a minimum of 18 semester units or 
(equivalent) in a major or area of emphasis; c) earn a 2.0 minimum grade point average (GPA) (http://www.sb1440.org/). This policy offers prospective transfer students a clear pathway to complete general education requirements, and lower-division major requirements within 60 semester units or less, without the concern of losing college credits. The AD-T includes two types of degrees: 1) Associate in Arts Degree for Transfer (AD-T) and 2) Associate in Science Degree for Transfer (AS-T).

\section{California state university.}

There are a few benefits of an AD-T at the receiving CSU campus. One benefit of this relatively new legislation is that students are guaranteed admission into the CSU system. Some factors that influence admissions are 1) local admission area-designated by the CSU Chancellor's Office; 2) program/major impaction (more applicants than available seats); 3) program/major impaction grade point average among the applicant pool for a specific major (http://www.sb1440.org/Counseling.aspx). One example, a transfer applicant with an $\mathrm{AD}-\mathrm{T}$ in Economics from Chabot College in Hayward, California (within the local admission area for CSU East Bay) may select a non-impacted CSU campus, such as CSU East Bay and choose Economics as their choice of major; this student would receive guarantee admissions and complete their baccalaureate degree at CSU East Bay. However, a student is not guaranteed admission into a specific CSU campus. Another example, a transfer applicant with an AD-T in Economics from Chabot College (outside of the local admission area for San José State University) may select an impacted CSU campus, such as San José State University (where all programs are 
impacted) and choose Economics as their choice of major. Depending on the GPA of the applicant pool, the student may fall below the GPA threshold and be denied admissions to San José State University and may be redirected to CSU East Bay or another CSU campus to earn their baccalaureate degree.

A second benefit from an AD-T is a guaranteed pathway to complete the last 60 units needed to earn a baccalaureate degree. The pathway is available to AD-T students in the form of a sample two-year academic plan that indicates their remaining requirements. In general, these plans are available online at their CSU campus and reference at the students' transfer orientation. In some cases, the AD-T process is straight-forward, when a student selects an $\mathrm{AD}-\mathrm{T}$ in a major, then applies to such major and gains admissions. For instance, a student with an $\mathrm{AD}-\mathrm{T}$ in Economics, may select an Economics major when applying to a CSU campus and gain admission to such CSU campus (pending impaction) or another CSU campus, then gain access to a sample twoyear academic plan outlining a clear path to their baccalaureate degree in Economics.

Lastly, an AD-T can reduce or eliminate the loss of credits. Some transfer students experience a loss of credits when their receiving institution does not award course equivalency from coursework completed at a community college. Such instances occur, because there is no equivalent course articulated. In some cases, a student has taken a similar course, but not similar enough to meet equivalency. Therefore, transfer 
students may be required to take additional courses or what some students might refer to as duplicate course work.

\section{Traditional Associate Degree in Business Administration}

Traditionally, an associate degree in business administration at California community colleges may be offered as an Associate of Arts degree or an Associate of Science degree. When researching the type of associate degrees in business administration offered at feeder community colleges to San José State University, two of six CCCs offer an Associate of Arts, rather than Associate of Science. These two institutions are De Anza College - a top feeder campus and its sister campus, Foothill College.

\section{Associate of Science for Transfer in Business Administration}

This section of the literature review will show how the Associate of Science for Transfer in Business Administration was developed at a California Community College and a California State University campus, specifically, San José State University.

\section{California community college.}

The Associate of Science for Transfer in Business Administration was informed by the existing model curriculum California Community Colleges used. This model curriculum provided a framework to create degrees that have some consistency throughout the region or state. In response to Senate Bill 1440 (2010) and 440 (2013), the CCC system initiated the use of the model curriculum to develop a transfer model 
curriculum, where business faculty from the CCC and the CSU work together to establish the Associate in Science for Transfer (AS-T) in Business Administration. Their guiding principle... "was to provide enough flexibility for CCCs and their destination CSUs (and for CSUs and their feeder CCCs) to work together to craft transfer degrees that work best for their students. Counterbalancing this flexibility is guidance on a set of courses that meets the needs of as many CSUs as possible, and that can be seamlessly provided by CCCs" (CCCCO, 2019a). Because the Business Administration degree has different concentrations at each CSU Campus, the AS-T in business administration at San José State University can be slightly more complicated.

\section{San José State University.}

At San José State University (SJSU), there is one Business Administration degree with 13 concentrations in the following areas: Accounting, Accounting Information Systems, Business Analytics, Corporate Accounting \& Finance, Entrepreneurship, Finance, General Business, Global Operations Management, Human Resource Management, International Business, Management, Management Information Systems, and Marketing. However, only seven concentrations have an AS-T: Business Analytics, Entrepreneurship, Finance, General Business, Global Operations Management, Human Resource Management and Management. Therefore, if a transfer student has an AS-T in Business Administration, they may receive admissions to SJSU, but they may not be able to graduate within two-years with their desired baccalaureate degree. One example, a transfer applicant with an AS-T in Business Administration from San José City College 
(within the local admission area for SJSU) may complete a AS-T in business administration, but upon completing the admissions application, selects Business Administration with a concentration in Accounting at San José State University, an impacted CSU campus (where all programs are impacted); depending on the GPA of the applicant pool, the student may fall below the GPA threshold and be denied admissions to SJSU and possibly be redirected to CSU East Bay or another CSU campus to earn their baccalaureate degree. Alternatively, if the student met the impaction criteria and gained admissions, since the Accounting concentration does not have a matching AS-T program, there is no guaranteed the student can complete their baccalaureate degree in two-years. An AS-T in Accounting and a few other concentrations are highly impacted programs, that require courses, which may not have enough sections to meet the student demand and may prohibit degree completion within two-years. Therefore, despite earning an AS$\mathrm{T}$ at their respective community college, completing the reminder 60 units within twoyears may not be feasible or guaranteed for all transfer students, pending their concentration.

In conclusion, the literature reviewed offered a comprehensive review of the relevant literature that informed this study. The review outlined five main topics. The first was the traditional transfer student pathway and the various definitions of a transfer student. The second topic illustrated why students begin their postsecondary education at a CCC, the challenges students face on completing the transfer mission and for those that do transfer, the challenges they face at the receiving four-year institution. The third topic 
covered the Associate Degree for Transfer at a CCC and CSU. The fourth topic reviewed the traditional Associate Degree in Business Administration. The fifth topic covered the Associate of Science for Transfer in Business Administration at the CCC and SJSU. This chapter informed the methodology used in this study. 


\section{Chapter Three: Methodology}

Several years have passed since Senate Bill 1440 (2010) and 440 (2013), and SJSU has not evaluated the AD-T program. This study is designed to examine the AS-T in business administration program, a subset of the $\mathrm{AD}-\mathrm{T}$ program. The purpose of this study is to examine how transfer students admitted to the Lucas College of Business at San José State University with an AS-T in business administration compare at baccalaureate degree completion to those admitted without an AS-T in business administration.

This chapter provides the specific procedures used to answer the research questions for this study. First, this chapter will present the research design and how the selected methodology supports the research questions this study aims to address. Second, the role of the researcher in this study is explained. Third, is a description of the context, population, and sampling. Fourth, is a description of the data collection process. Lastly, the chapter will conclude with a detailed account of the data analysis procedures.

\section{Research Design}

This research design is inaugural for the Associate of Science for Transfer in Business Administration program at San José State University. This design attempts to uncover the preliminary outcomes of this program. A quasi-experimental design is used to evaluate the effectiveness of the AS-T program in Business Administration. The researcher did not assign students (participants) to the program group nor the comparison 
group. These groups existed before the researcher became interested in this study, that is, they are naturally occurring as the students self-selected to participate or not participate in the AS-T program for Business Administration. Therefore, the groups in this study are non-equivalent groups. The researcher will identify students who complete an AS-T in Business Administration as the program group and students who did not complete an AS$\mathrm{T}$ in Business Administration as the comparison group.

The research design will include cross-sectional and longitudinal components. The cross-sectional component will include all transfer students who were admitted as Business Administration students and graduated with a Business Administration degree. The snapshot of this population will occur in June 2019. The longitudinal component includes business administration students from the fall 2015 and fall 2016 upper-division transfer cohorts.

\section{Role of the Researcher}

The researcher has over 10-years of experience assisting undergraduate students complete their baccalaureate degree, many of which, transferred from California Community Colleges to a CSU campus. Shortly after the passage of Senate Bill 1440 (2010), the Student Transfer Achievement Reform (STAR) Act, the researcher gained a working knowledge of this state legislature. In March 2016, the researcher became employed by the Lucas College of Business at San José State University as a student services professional charged with oversight of the College's student success center, 
which aims to help undergraduate business students achieve their academic, career and personal goals. Since then, the researcher has gained proficiency with the AS-T in business administration program. Identifying the preliminary outcomes of the AS-T program could offer an opportunity to improve the implementation and practice of the AS-T in business administration. The outcomes could be shared with the Lucas College of Business, Articulation Office, Admissions Office, and at the annual Community College Counselor's Conference. The researcher decided to pursue a career in higher education because of their work experience serving first-generation, low-income and students of color aspiring to transfer to a four-year institution to complete a baccalaureate degree. Examining the preliminary outcomes of an educational policy designed to support degree completion, through an equity and social justice lens, is of personal and professional importance to the researcher.

The researcher had no role in collecting the existing data. The researcher requested specific data about the fall 2015 and fall 2016 cohort and a variety of student characteristics to identify if any predictors exist in this study. The deidentified data set was provided by the Office of Institutional Effectiveness and Analytics at SJSU.

\section{Setting, Population and Sample}

The setting of this study is San José State University, one of 23 campuses in the California State University System. SJSU is a large and diverse comprehensive state university in the heart of Silicon Valley. In fall 2017, the university enrolled over 33,000 
students of which approximately 27,780 were undergraduate students. Of all undergraduates enrolled, 40 percent were Asian, 29.9 percent Hispanic, 16.6 percent White, 9.4 percent Other, 3.5 percent Black, 0.4 percent Pacific Islander and 0.1 percent Native American. The university is designated an Asian American Native American Pacific Islander Serving Institution (AANAPISI) and a Hispanic-Serving Institution (HSI). Among new undergraduate students enrolled, about 50 percent are new transfer students (SJSU, 2018a).

The study population are upper-division transfer students majoring in Business Administration, admitted to SJSU from California Community Colleges. In the past five academic years, the average number of matriculated students is about 830 (SJSU, 2018a). The population for this study was selected for two important reasons. First, the Business Administration degree is the most popular degree awarded in the CSU system and SJSU is among the top four CSU campuses that award the most Business Administration degrees (California State University, 2018). Second, for the past five academic years, the College of Business had the largest undergraduate student population at SJSU with about 5,000 to 5,500 students enrolled annually. Data from the Office of Institutional Effectiveness and Analytics revealed the following racial ethnic student demographics of new transfer students with California residency at SJSU. In fall 2015, the new transfer students with California residency totaled 802 . The racial/ethnic diversity included 44.0 percent Asian, 20.0 percent Hispanic, 20.0 percent White, 11.1 percent Other, 2.7 percent Black, 0.4 percent Pacific Islander and 1.9 percent foreign. In fall 2016, the new transfer 
students with California residency reached 909 . The racial/ethnic diversity comprised of 44.0 percent Asian, 20.2 percent Hispanic, 21.7 percent White, 7.7 percent Other, 1.3 percent Black, 0.3 percent Pacific Islander and 4.4 percent foreign. The transfer student cohorts for fall 2015 and fall 2016, mirror the racial ethnic diversity of the university. The study drew from this general population to establish a sample frame.

The original sample frame intended to include the fall 2015 and fall 2016 transfer cohorts admitted to the Lucas College of Business from a California Community College. However, when the Director of the Office Institutional Effectiveness and Analytics went through the process of compiling the data set, he found the data for the fall 2015 cohort was unreliable and he could not ensure validity. Thus, the sample frame was reduced to the fall 2016 cohort. In total, the dataset consisted of 44 data elements that spanned three main categories. The first category included student academic indicators such as: courselevel grades, term-by-term summaries of grades, units attempted, units earned, term of admission and type of admission. The second category comprised of student demographic indicators such as: gender, age, primary ethnicity, and whether or not each parent attended or graduated from college. The third category introduced financial aid indicators such as: whether or not the student submitted a Free Application for Federal Student Aid application or received major need-based grant aid or whether federal workstudy was offered. This sampling frame provided the structure for the study. 
From this sampling frame, the researcher used a stratified sampling method to sample the population of students into three strata. The first group are comprised business transfer students from a California community college with a traditional Associate Degree in Business Administration. The second group included those who earned an Associate of Science for Transfer (AST) in Business Administration. These students must have been awarded an AS-T in Business Administration at their respective California community college and were later verified by the SJSU Admissions Office. The third group constitute business students that transferred from a California community college without an Associate Degree of any kind. These sub-groups were determined from the dataset provided by the Office of Institutional Effectiveness and Analytics at SJSU. The sample size was projected to include more than 100 students from the fall 2016 cohort.

\section{Data Collection}

When transfer students apply for admission, they have the option to self-report if they plan to earn an AD-T degree. If a student is admitted, the Admissions staff at SJSU will verify if the AD-T degree was awarded. Since fall 2015, all AD-T admits have been routinely verified and added to their respective student groups in the student information system by Admissions staff. These student record data are available and most reliable for the fall 2016 cohort. Permission was requested via the Office of Institutional Effectiveness and Analytics at SJSU. The Office built a specific dataset per the instructions of the researcher. The dataset was deidentified which eliminated the 
possibility of identifying specific students. The dataset included student records for the fall 2016 cohort admitted as an upper-division transfer student from a California community college to the Lucas College of Business and those students with a verifiedAS-T in business administration were denoted accordingly. The data were provided in a Microsoft Excel format for the researcher to code and recode student records as needed, then imported into IBM SPSS statistical software for analysis.

\section{Variables}

A broad range of variables are included in this study to best answer the proposed research questions. The most important variables consist of seven data elements: Associate of Science for Transfer (AS-T) status, Business Administration concentration (1 of 13 concentrations), degree completed, primary ethnicity and detailed ethnicity/nationality when specified, and whether or not the student received major needbased grant aid (Pell, Cal Grant, SUG), total SJSU units earned and time to degree, see Table 1 for further details.

Table 1

Summary of Variables

\begin{tabular}{lccccc}
\hline Variable & $\begin{array}{c}\text { Independent } \\
\text { Variable }\end{array}$ & $\begin{array}{c}\text { Dependent } \\
\text { Variable }\end{array}$ & $\begin{array}{c}\text { Confounding } \\
\text { Variable }\end{array}$ & $\begin{array}{c}\text { Operational } \\
\text { Measure }\end{array}$ & $\begin{array}{c}\text { Level of } \\
\text { Measurement }\end{array}$ \\
\hline $\begin{array}{l}\text { Associate of } \\
\text { Science for }\end{array}$ & Yes & & AS-T in & Binary \\
Transfer (AS-T) & & & Business & (Yes/No) \\
in Business & & & Administration & Discrete \\
Administration & & & verified & \\
\hline
\end{tabular}




\begin{tabular}{|c|c|c|c|c|c|}
\hline Variable & $\begin{array}{c}\text { Independent } \\
\text { Variable }\end{array}$ & $\begin{array}{l}\text { Dependent } \\
\text { Variable }\end{array}$ & $\begin{array}{l}\text { Confounding } \\
\text { Variable }\end{array}$ & $\begin{array}{c}\text { Operational } \\
\text { Measure }\end{array}$ & $\begin{array}{c}\text { Level of } \\
\text { Measurement }\end{array}$ \\
\hline $\begin{array}{l}\text { Baccalaureate } \\
\text { Degree } \\
\text { Completed }\end{array}$ & & Yes & & $\begin{array}{c}\text { Degree } \\
\text { awarded }\end{array}$ & $\begin{array}{c}\text { Binary } \\
\text { (Yes/No) } \\
\text { Discrete }\end{array}$ \\
\hline $\begin{array}{l}\text { Business } \\
\text { Administration } \\
\text { Concentration }\end{array}$ & & & Yes & 13 options & Nominal \\
\hline Ethnicity & & & Yes & $\begin{array}{c}\text { Asian, } \\
\text { Hispanic, } \\
\text { White, Other }\end{array}$ & Nominal \\
\hline $\begin{array}{l}\text { Major Need- } \\
\text { Based Grant } \\
\text { Aid }\end{array}$ & & & Yes & $\begin{array}{l}\text { Pell, Cal } \\
\text { Grant, SUG }\end{array}$ & Nominal \\
\hline $\begin{array}{l}\text { Total SJSU } \\
\text { Units }\end{array}$ & & Yes & & $\begin{array}{l}\text { Actual units } \\
\text { carned }\end{array}$ & $\begin{array}{c}\text { Ratio } \\
\text { (Continuous) }\end{array}$ \\
\hline Time to Degree & & Yes & & $\begin{array}{l}\text { Number of } \\
\text { years/terms }\end{array}$ & $\begin{array}{c}\text { Ratio } \\
\text { (Continuous) }\end{array}$ \\
\hline
\end{tabular}

Source: SJSU Institutional Effectiveness \& Analytics

This study used a single independent variable, AS-T in business administration earners, which were verified by the SJSU Admissions Office. The independent variable is dichotomous. The comparison group are non-AS-T business administration students, which did not complete an AS-T in business administration at their prior CCC.

There are several dependent variables in this study. First, is degree completion. This variable is dichotomous and indicates which students completed their baccalaureate degree within six semesters or by spring 2019. Second, the total number of SJSU units earned by graduates. This variable revealed if students complete their baccalaureate within 60 units earned at SJSU. Lastly, is the time to degree variable, which was measured by the number of years/terms needed to earn a baccalaureate degree upon transfer. The calculation of the number of years to graduation was done by academic year. For example, a student who graduated within two academic years, would have a 
two-year graduation rate if they completed their degree within the Fall 2017 - Spring 2018 academic year, which could be a graduation term of either the fall 2017, spring 2018 , or summer 2018 term. The calculation of the number of terms to graduation included two terms per year. For instance, students that graduate by the spring 2018 term, were counted as a four-term graduate and those that graduate by the summer 2018 term, were counted as four and a half-term graduate.

The researcher selected several confounding variables to determine whether they affect the relationship between the predictors and a predicted variable. First, a student's racial ethnic background may be a leading confounding variable. Second, a business administration - concentration may show a relationship with degree completion. Third, whether or not the student received major need-based grant aid (Pell, Cal Grant, SUG), may serve as a proxy for socio-economic status.

\section{Data Analysis Procedures}

The researcher reviewed the data file to ensure the data requested were the data received. The researcher was responsible for cleaning and organizing the data, and ultimately preparing the data for analysis. Next, the variables were recoded for statistical analysis. A codebook was used to document important information, such as, decisions made regarding problems with the data. The problems that arose included missing data, out-of-range values, invalid values, and unusual values or obvious errors. When the issue of missing data arose, the researcher examined for patterns of missing data across 
multiple variables and assessed how many cases needed to be removed. Once the data were prepped for analysis, the data were imported into IBM SPSS for statistical analysis.

This study utilized the following statistical techniques to answer the research questions. There are two parametric tests used in this study. First, an IndependentSample $\mathrm{T}$ test is used to compare means of two groups at one point in time. Second, the One-Way Analysis of Variance (ANOVA) is used to compare the means of three or more independent groups to assess if there is statistical evidence that the associated population means are significantly different. This test requires a dependent variable that is continuous and an independent variable that is categorical. The non-parametric ChiSquare Test of Independence is used to examine association between nominal variables.

\section{Reliability and Validity}

The Office of Institutional Effectiveness and Analytics provided assurance of the reliability and validity of the data set they provided for this study. In addition, the researcher ensured that the population for the fall 2016 cohort of upper-division transfer students from California community colleges into the Lucas College of Business is over 800 students. The researcher confirmed the appropriate assumptions were met for each statistical test.

Student cases with incomplete data were identified and removed, if necessary, while ensuring the sample size and characteristics were held in tack. One possible threat to internal validity are variables not accounted for in this study, such as the increase of 
class size and/or number of sections for a course denoted as a "bottle-neck" course (limited seats and/or sections to meet student demand) or gender, a potential independent variable that was anticipated to have a low response rate. This also speaks to a limitation of using secondary data from an institutional database, where the data used in this study is limited to the data collected from a student's college application, SJSU student records and the Free Application for Federal Student Aid information provided by the CSU Chancellor's Office to SJSU.

This chapter discussed the details of the methodology used to answer the proposed research questions for this study. First, the rationale and specifics of the research design was presented to showcase how the methodology aims to address the research questions. Second, the role of the researcher was made known. Third, a detailed narrative of the setting, population, and sample was presented to provide a clear understanding of the context for this study. Fourth, the data collection process and explanation of the variables showcased the nuances of this research. Fifth, this chapter outlined the data analysis procedures and statistical methods used to analyze nominal and ratio-level data. Lastly, the reliability and validity of this study was explained. The next chapter will present the findings from the statistical analysis performed. 


\section{Chapter Four: Findings}

This study used quantitative analysis to examine the preliminary outcomes of the AS-T in Business Administration program at San José State University, an investigation that had yet to be done. Specifically, this study revealed if AS-T earners earn their baccalaureate degree within two-years of transfer. A second research question compared how AS-T in business administration earners and non-AS-T in business administration earners fare at degree completion. Lastly, this study examined the nature of this relationship between URM and non-URM students.

\section{Characteristics of the Sample}

The original sample included 954 students. However, during the data cleaning process 13 students earned less than 60 transfer units from their prior institution and thus, are not considered an upper-division transfer. These students were likely international admits, former students returning or special admits, such as veterans or student-athletes. Since a minimum of 60 units is required for an AS-T, these admits were ineligible for an AS-T degree, therefore they were excluded from this study. As a result, the Fall 2016 cohort was reduced to 941 students, which comprised of 208 (22.1\%) AS-T students and 733 (77.9\%) non-AS-T students made up of 138 (14.7\%) AA degree earners and 595 (63.2\%) transfers who did not earn an associate degree of any type.

This cohort is highly representative of the transfer population, as the sample was taken directly from the sampling frame. The following characteristics are used to 
illustrate the diverse student demographics of this cohort. Among this cohort, the ethnic background of these students consisted of 460 (48.9\%) Asian, 202 (21.5\%) Hispanic, 192 (20.4\%) White, and 87 (9.2\%) Other. There were too few students from the following ethnic backgrounds: African-American, Native-American, and Pacific Islander, to include in the statistical analysis; therefore, the researcher lumped these students into the Other category. The gender make-up was 419 (44.5\%) female and $522(55.5 \%)$ male. In terms of age, $12(1.3 \%)$ were 19 years old and under, 641 (68.1\%) were 20-24 years of age, $188(20 \%)$ were $25-29$ years of age, $57(6.1 \%)$ were $30-34$ years of age and 43 (4.6\%) were 35-59 years of age. Regarding the highest level of education completed by their mother, $173(18.4 \%)$ did not specify any college education, $403(42.8 \%)$ had no college education, $183(19.4 \%)$ had some college education, and $182(19.3 \%)$ held a bachelor's degree or higher. Regarding their father's level of education, 121 (12.9\%) did not specify any college education, 395 (42\%) had no college education, 181 (19.2\%) had some college education and 244 (25.9\%) earned a bachelor's degree or higher.

Student's financial aid information were obtained to disclose whether or not they received major need-based grant aid (Pell, Cal Grant, SUG). These data served as a proxy for a student's socio-economic status. As mentioned earlier, these data were supplied from the CSU Chancellor's Office to SJSU. In terms of dependent status for financial aid, $316(33.6 \%)$ were considered independent, 373 (39.6\%) identified as dependent and 252 (26.8\%) had missing data. Concerning the students who ever received a federal loan, $676(71.8 \%)$ were ineligible or never applied, $265(28.2 \%)$ were 
federal loan recipients. The following information makes known if the student ever received a major need-based grant aid. Regarding the federal Pell grant - based on the expected family contribution, $478(50.8 \%)$ were ineligible or never applied and 463 (49.2\%) received a federal grant. Regarding the California Grant - based on GPA and financial need to cover tuition fees, 718 (76.3\%) were ineligible or never applied, and $223(23.7 \%)$ were awarded a California grant. In terms of the State University Grant based on California residency, submission of FAFSA by the priority deadline and an expected family contribution of $\$ 5,000$ or less, $603(64.1 \%)$ were ineligible or never applied and $338(35.9 \%)$ received this grant. The median expected family contribution for financial aid recipients was $\$ 798$.

The following information exhibits the institutional characteristics of California community college transfer students to San José State University. In terms of institutional characteristics, $615(65.4 \%)$ transfer from a California community college within the San José State University service area, 284 (30.2\%) transfer from a California community college outside the San José State University service area, and the remaining 42 (4.4\%) transfer from an in-state institution (public or private) or out-of-state institution. Most of the transfer students come from a Califomia community college in the Santa Clara county at $580(61.6 \%), 218(23.2 \%)$ come from another Bay Area county and $143(15.2 \%)$ come from a non-Bay Area county. Of the transfer students from Santa Clara county, most transfer from De Anza College at 253 (26.9\%), which usually ranks among the top five transfer community colleges in California. 
The academic characteristics of these transfer students showcase a snapshot of their academic profile at the start of their undergraduate experience at San José State University. Transfer students are admitted to all 13 concentrations in the Bachelor of Science in Business Administration program. The top five concentrations are 191 (20.3\%) in Accounting, 149 (15.8\%) in Management, 143 (15.2\%) in Finance, 136 (14.5\%) in Marketing, and 66 (7.0\%) in Management Information Systems. The transfer GPA statistics indicate a 3.2 mean GPA with a 0.4 standard deviation. The minimum GPA was 2.1 and maximum GPA was 4.0. The number of transfer units earned at their respective CCCs include a mean of 81.0 units with a 17.6 standard deviation. The median is 76.8 within a minimum of 60 units and maximum of 212 units.

The academic performance for the sample population provide an overview of a few relevant educational outcomes. The data were collected at the end of June 2019, at which point, 729 (77.5\%) transfer students earned a Bachelor of Science degree, 4 (.4\%) earned a Bachelor of Arts degree and 208 (22.1) had yet to earn their degree, of which, 104 were not enrolled the 2018-2019 academic year. The top five degrees awarded by concentration are 140 (14.9\%) in Accounting, $117(12.4 \%)$ in Marketing, $106(11.3 \%)$ in Management, 92 (9.8\%) in Finance, and 80 (8.5\%) in Management Information Systems. Among the fall 2016 cohort, transfer students finished their degrees in the following terms: $2(.2 \%)$ by spring $2017,13(1.4 \%)$ by fall $2017,308(32.7 \%)$ by spring 2018,51 (5.4\%) by summer 2018, $247(26.2 \%)$ by fall 2018, and $112(11.9 \%)$ by spring 2019 . 


\section{Inferential Statistics}

The researcher used a quantitative methodology to answer the research questions and performed the appropriate statistical methods to test each hypothesis. An Independent Sample T-Test was used to determine the statistical difference among the means for two groups, using the conventional $p<.05$. The assumptions for this test were verified. The One-Way Analysis of Variance (ANOVA) test was used to determine statistical difference among the means of three or more groups, also using the conventional $p<.05$. The data were reviewed to determine that all the assumptions required for ANOVA were met. In cases when there was a violation of the assumption of variance the robust test of equality of means was used when unequal variance of means occurred. In which case, the post hoc test Games-Howell was used to identify statistical significance. Lastly, the Chi Square Test of Independence was used to determine the association between categorical variables at a $p<.05$. The following reports showcase the results from the inferential statistics performed.

\section{Research question one.}

The first research question examines if AS-T in business administration earners finish their degree within two-years of transfer. For this research question, the alternative hypothesis declares AS-T earners will complete their baccalaureate degree in less than or equal to two-years after transfer. When testing this hypothesis, the non-AS-T group ( $M=$ $2.50, S D=0.50)$ was statistically significantly different than the AS-T group $(M=2.41$, $S D=0.50)$, as determined by the $t(731)=1.97, p<.05$. The average time to degree for 
the AS-T group $(M=2.41)$ was less than that of the non-AS-T group $(M=2.50)$, which is statistically significant and important to note. Although there is a statistical significance between the two groups, these results suggest the average time to degree completion for AS-T earners is greater than two-years after transfer. Therefore, the null hypothesis is not rejected.

\section{Research question two.}

As mentioned earlier, the second research question aims to answer, "how do AS-T business administration earners compare to non-AS-T business administration earners at finishing their degree?" If the AS-T program meets the desired program outcome, then AS-T earners will earn their baccalaureate degree in less time and within 60 units earned at SJSU than non-AS-T earners.

The second research question has two components and therefore two sets of hypotheses statements. The alternative hypothesis for the first component states the AS$\mathrm{T}$ in business administration earners will earn their baccalaureate degree in less time (years/terms). The One-Way ANOVA test reveals there is no statistical significance. Therefore, the null hypothesis is not rejected; AS-T earners will complete their baccalaureate degree in approximately the same amount of time or in more time than non-AS-T earners, as shown in Table 2. 
Table 2

Time to Degree by Degree Type

\begin{tabular}{lcccccc}
\hline & & \multicolumn{2}{c}{ Years } & & \multicolumn{2}{c}{ Terms } \\
\cline { 3 - 4 } \cline { 6 - 7 } Degree Type & $n$ & $M(S D)$ & $95 \% \mathrm{CI}$ & & $M(S D)$ & $95 \% \mathrm{CI}$ \\
\hline AA & 104 & $2.46(0.51)$ & {$[2.36,2.56]$} & & $4.57(0.73)$ & {$[4.42,4.71]$} \\
AS-T & 167 & $2.41(0.50)$ & {$[2.34,2.49]$} & & $4.57(0.78)$ & {$[4.45,4.69]$} \\
None & 462 & $2.51(0.50)$ & {$[2.47,2.56]$} & & $4.70(0.74)$ & {$[4.63,4.76]$} \\
\hline Total & 733 & $2.48(0.50)$ & {$[2.45,2.52]$} & & $4.65(0.75)$ & {$[4.59,4.70]$} \\
\hline
\end{tabular}

Note. $\mathrm{CI}=$ confidence interval.

The second component of the first research question investigates whether AS-T students complete their degree within 60 units earned at SJSU. Therefore, the alternative hypothesis indicates, AS-T earners will complete their baccalaureate degree in business administration more efficiently by earning fewer units at SJSU. When testing this hypothesis, there was a statistically significant difference among degree type as determined by One-Way ANOVA $F(2,730)=15.230, p<.05$. A Tukey HSD post hoc test revealed the number of SJSU cumulative units was on average statistically significantly lower for transfer students with an AS-T degree $(M=59.41, S D=6.28)$ compared to transfer students without an associate degree $(M=62.75, S D=7.09)$. There was no statistically significant difference between transfer students with an AA degree and AS-T degree, and transfer students with an AA degree and those without an associate degree (AA or AS-T), as shown in Table 3. A sensitivity analysis was conducted using a $p<.10$ and found by way of a Tukey HSD post hoc test, that the number of SJSU cumulative units was on average statistically significantly lower for transfer students with an AS-T degree $(M=59.41, S D=6.28)$ compared to transfer students without an AA 
degree $(M=61.16, S D=6.28)$. The sensitivity analysis shows more significant differences at the $90 \%$ confidence interval.

In addition, non-statistically significant findings reveal that on average, the mean SJSU cumulative units earned were lower among AS-T earners, followed by AA earners, than students with no degree of any type, which supports the alternative hypothesis. Since this research study sampled the population directly, that is, the fall 2016 cohort were the sampling frame, these descriptive statistics have greater meaning as a representation of the population, not a sample of the population.

Table 3

SISU Cumulative Units Earned

\begin{tabular}{lccc}
\hline Degree Type & $n$ & $M(S D)$ & $95 \% \mathrm{CI}$ \\
\hline AA & 104 & $61.16(6.28)$ & {$[59.94,62.38]$} \\
AS-T & 167 & $59.41(6.28)^{*}$ & {$[58.45,60.37]$} \\
None & 462 & $62.75(7.09)$ & {$[62.10,63.40]$} \\
\hline Total & 733 & $61.76(6.94)$ & {$[61.26,62.27]$} \\
\hline
\end{tabular}

Note. $\mathrm{CI}=$ confidence interval. ${ }^{*}$ Significant difference between AS-T and none, $p<.05$.

In addition, there are other student outcome variables with ratio level measurements suitable for ANOVA testing, as shown in Table 4. Among these variables, there was one statistically significant difference identified among degree type and cumulative units. As determined by the Robust Tests of Equality of Means with a Welch statistic of 5.49, $p<.05$. The post hoc test Games-Howell revealed the cumulative units earned was on average statistically significantly higher for the transfer students with an 
AA degree $(M=150.40, S D=21.36)$ when compared to transfer students without an associate degree $(M=143.20, S D=15.31)$, resulting in a mean difference of 7.19 and $S E$ of 2.21. Cumulative units earned is SJSU units earned plus external units earned. The external units include all college-level transfer credit accepted by SJSU admissions, which may exceed the maximum of 70 units from a CCC counted toward the 120 units required for a baccalaureate degree.

Table 4

Summary of Other Student Outcome Variables by Degree Type

\begin{tabular}{|c|c|c|c|c|}
\hline & & Cumulative Units & Cumulative GPA & $\begin{array}{c}\text { SJSU Cumulative } \\
\text { GPA }\end{array}$ \\
\hline $\begin{array}{l}\text { Degree } \\
\text { Type }\end{array}$ & $\mathrm{n}$ & $\begin{array}{l}M(S D) \\
95 \% \mathrm{CI}\end{array}$ & $\begin{array}{l}M(S D) \\
95 \% \mathrm{CI}\end{array}$ & $\begin{array}{l}M(S D) \\
95 \% \mathrm{CI}\end{array}$ \\
\hline $\mathrm{AA}$ & 104 & $\begin{array}{c}150.40 *(21.36) \\
{[146.24,154.55]}\end{array}$ & $\begin{array}{l}3.24(0.37) \\
{[3.17,3.31]}\end{array}$ & $\begin{array}{l}3.19(0.44) \\
{[3.11,3.28]}\end{array}$ \\
\hline AS-T & 167 & $\begin{array}{c}145.19(22.29) \\
{[141.78,148.59]}\end{array}$ & $\begin{array}{l}3.19(0.35) \\
{[3.13,3.24]}\end{array}$ & $\begin{array}{l}3.17(0.41) \\
{[3.11,3.23]}\end{array}$ \\
\hline None & 462 & $\begin{array}{c}143.20(15.31) \\
{[141.80,144.60]}\end{array}$ & $\begin{array}{l}3.22(0.37) \\
{[3.18,3.25]}\end{array}$ & $\begin{array}{l}3.16(0.44) \\
\lceil 3.12,3.20\rceil\end{array}$ \\
\hline Total & 733 & $\begin{array}{c}144.68(18.18) \\
{[143.36,145.99]}\end{array}$ & $\begin{array}{l}3.22(0.37) \\
{[3.19,3.24]}\end{array}$ & $\begin{array}{l}3.17(0.43) \\
\lceil 3.14 .3 .20\rceil\end{array}$ \\
\hline
\end{tabular}

Note. $\mathrm{CI}=$ confidence interval. $*$ Significant difference between AA and none, $p<.05$.

The researcher examined the possible association between several categorical variables using the Chi-Square Test of Independence. The first set of analysis was performed using the AS-T status variable. As shown in Table 5, only a few results suggest statistically significant findings at the $p<.05$ level. First, there was a very strong association between AS-T status and the degree concentration (i.e. Business 
Administration - Entrepreneurship). That is, students with an AS-T were overrepresented in the following concentrations: Entrepreneurship, International Business, and Management. Second, there was also a very strong association between AS-T status and ethnicity. Students with an AS-T were overrepresented in the ethnic categories of Other and Hispanic, and underrepresented in the Asian student population. Third, there was a very strong association between AS-T students and recipients of a federal loan. Fourth, there was a moderate association between AS-T students and recipients of a state university grant (SUG).

Table 5

Summary of Significant Chi-Square Associations with AS-T Status Variable

\begin{tabular}{lccc}
\hline Variable & $\mathrm{N}$ & $\mathrm{df}$ & Sig. \\
\hline Degree Conc. & 941 & 14 & $.00^{*}$ \\
Ethnicity & 941 & 3 & $.00^{*}$ \\
Federal Loan & 941 & 1 & $.01^{*}$ \\
SUG Grant & 941 & 1 & $.03^{*}$ \\
\hline Note. Conc. = concentration. SUG $=$ State University Grant, ${ }^{*} p<.05$.
\end{tabular}

The second set of analysis was performed using the degree awarded variable. As shown in Table 6, only a few results suggest statistically significant findings at the $p<$ .05 level. First, there was a very strong association between degree awarded and the degree concentration (i.e. Business Administration - Accounting). That is, students awarded a degree were overrepresented in several concentrations: Accounting, Finance, General Business, Human Resource Management, Management, Management 
Information Systems, and Marketing. Second, there was also a very strong association between degree awarded status and ethnicity. Students who did not earn a degree at the point in which these data were collected, were overrepresented in the ethnic categories of Other and Hispanic, and underrepresented in the Asian student population. Third, there was also a very strong association between degree award status and whether or not a student received a federal loan. More specifically, students who did not earn a degree were underrepresented in the non-federal recipient group. Students who did not earn a degree were overrepresented in the federal loan recipient group. Fourth, there was a moderate association between degree awarded status and CAL grant recipients. That is, student who did not earn a degree were underrepresented in the CAL grant recipient group.

Table 6

Summary of Significant Chi-Square Associations with Degree Awarded Variable

\begin{tabular}{lccc}
\hline Variable & $\mathrm{N}$ & $\mathrm{df}$ & Sig. \\
\hline Degree Conc. & 941 & 14 & $.00^{*}$ \\
Ethnicity & 941 & 3 & $.00^{*}$ \\
Federal Loan & 941 & 1 & $.00^{*}$ \\
CAL Grant & 941 & 1 & $.03^{*}$ \\
\hline Note. Conc. = concentration. CAL $=$ California, ${ }^{*} p<.05$.
\end{tabular}




\section{Research question three.}

The last research question examines "are there significant differences in baccalaureate degree completion between URM and non-URM students who transfer with an $\mathrm{AD}-\mathrm{T}$ in business administration?" For this research question, the alternative hypothesis indicates, URM students will complete their baccalaureate degree in business administration in less time (years/terms). The ethnicities included in the URM group were Asian, Hispanic, and Other, whereas the non-URM group included Whites. Asians were included in the URM group, because SJSU has several Asian sub-populations, some in which include students from underrepresented or underserved communities, such as, Vietnamese and Pilipino students. When testing this hypothesis for years, using an Independent-Sample T Test, the Levene's test for equality of variances was found to be violated, so a $t$ statistic not assuming homogeneity of variance was used. As determined by the $t(225.73)=2.86, p<.05$, the URM group $(M=2.51, S D=0.50)$ was statistically significantly higher than non-URM group $(M=2.38, S D=0.50)$. When testing this hypothesis for the number of terms to degree, using an Independent-Sample T Test, the URM group $(M=4.68, S D=0.74)$ was statistically significantly higher than the nonURM group $(M=4.54, S D=0.79)$, as determined by the $t(731)=1.98, p<.05$.

In addition, this study disaggregated the race and ethnicity variable and performed a One-Way Analysis of Variance (ANOVA) to compare the means of the four independent groups (Other, Asian, Hispanic and White). When testing this hypothesis, there was a statistically significant difference among the transfer students by race and 
ethnicity as determined by the Robust Tests of Equality of Means with a Welch statistic of $5.14, p<.05$. The post hoc test Games-Howell revealed that the number of years to time to degree was on average statistically significantly higher for Asian students ( $M=$ $2.54, S D=0.50)$ when compared to White students $(M=2.38, S D=0.50)$, resulting in a mean difference of 0.16 and $S E$ of .04 , as shown in Table 7. The results in this table also show that the time (years/terms) to degree completion are also indistinguishable between Hispanic and White students.

Table 7

Time to Degree by Race and Ethnicity

\begin{tabular}{lcccccc}
\hline & & \multicolumn{2}{c}{ Years } & & \multicolumn{2}{c}{ Terms } \\
\cline { 3 - 4 } \cline { 6 - 7 } Race/Ethnicity & $n$ & $M(S D)$ & $95 \% \mathrm{CI}$ & & $M(S D)$ & $95 \% \mathrm{CI}$ \\
\hline Other & 59 & $2.37(0.48)$ & {$[2.24,2.50]$} & & $4.56(0.75)$ & {$[4.37,4.76]$} \\
Asian & 381 & $2.54 *(0.50)$ & {$[2.49,2.59]$} & & $4.66(0.71)$ & {$[4.59,4.73]$} \\
Hispanic & 146 & $2.47(0.50)$ & {$[2.39,2.56]$} & & $4.76(0.79)$ & {$[4.63,4.89]$} \\
White & 147 & $2.38(0.50)$ & {$[2.29,2.46]$} & & $4.54(0.79)$ & {$[4.41,4.67]$} \\
\hline Total & 733 & $2.48(0.50)$ & {$[2.45,2.52]$} & & $4.65(0.75)$ & {$[4.59,4.70]$} \\
\hline
\end{tabular}

Note. $\mathrm{CI}=$ confidence interval. ${ }^{*}$ Significant difference between Asian and White, $p<.05$.

Again, using the same student outcome variables with ratio-level measurements the researcher tested against race and ethnicity by way of the One-Way ANOVA, as shown in Table 8. Among these variables, there were multiple statistically significant differences identified. First, there was a statistically significant difference in SJSU cumulative units earned by race and ethnicity as determined by the Robust Tests of Equality of Means with a Welch statistic of $3.68, p<.05$. The post hoc test GamesHowell revealed the number of SJSU cumulative units earned was on average, 
statistically significantly lower for students in the Other category $(M=59.69, S D=5.76)$, when compared to transfer students who identified as Asian $(M=62.30, S D=6.05)$, resulting in a mean difference of -2.60 and $S E$ of 0.81 . Second, there was a statistically significant difference in cumulative GPA by race and ethnicity as determined by OneWay ANOVA $F(3,729)=16.51, p<.05$. A Tukey HSD post hoc test revealed the cumulative GPA was on average statistically significantly lower for Hispanic students ( $M$ $=3.04, S D=0.36)$ when compared to Asian students $(M=3.28, S D=0.36)$ and White students $(M=3.26, S D=0.35)$. Lastly, there was a statistically significant difference in SJSU cumulative GPA by race and ethnicity as determined by One-Way ANOVA $F(3$, $729)=16.22, p<.05$. A Tukey HSD post hoc test revealed the SJSU cumulative GPA was on average, statistically significantly lower for Hispanic students $(M=2.95, S D=$ $0.42)$ when compared to Asian $(M=3.23, S D=0.41)$, White students $(M=3.23, S D=$ $0.44)$, and Other students $(M=3.17, S D=0.43)$.

Table 8

Summary of Other Student Outcome Variables by Race and Ethnicity

\begin{tabular}{lccccc}
\hline & & Cum. Units & $\begin{array}{c}\text { SJSU } \\
\text { Cum. Units }\end{array}$ & Cum. GPA & $\begin{array}{c}\text { SJSU } \\
\text { Cum. GPA }\end{array}$ \\
\hline Race/ & $\mathrm{n}$ & $M(S D)$ & $M(S D)$ & $M(S D)$ & $M(S D)$ \\
Ethnicity & & $95 \% \mathrm{CI}$ & $95 \% \mathrm{CI}$ & $95 \% \mathrm{CI}$ & $95 \% \mathrm{CI}$ \\
\hline Other & 59 & $150.66(25.82)$ & $59.69 *(5.76)$ & $3.16(0.35)$ & $3.17(0.43)$ \\
& & {$[143.94,157.39]$} & {$[58.19,61.19]$} & {$[3.07,3.26]$} & {$[3.05,3.28]$} \\
Asian & \multirow{2}{*}{141} & $144.30(18.09)$ & $63.30(6.05)$ & $3.28(0.36)$ & $3.23(0.41)$ \\
& & {$[142.48,146.12]$} & {$[61.69,62.91]$} & {$[3.24,3.31]$} & {$[3.18,3.27]$} \\
Hispanic & \multirow{2}{*}{146} & $144.47(16.84)$ & $61.58(9.13)$ & $3.04 *(0.36)$ & $2.95^{*}(0.42)$ \\
& & {$[141.72,147.23]$} & {$[60.09,63.08]$} & {$[2.98,3.10]$} & {$[2.88,3.02]$}
\end{tabular}




\begin{tabular}{lccccc}
\hline & & Cum. Units & $\begin{array}{c}\text { SJSU } \\
\text { Cum. Units }\end{array}$ & Cum. GPA & $\begin{array}{c}\text { SJSU } \\
\text { Cum. GPA }\end{array}$ \\
\hline Race/ & $\mathrm{n}$ & $M(S D)$ & $M(S D)$ & $M(S D)$ & $M(S D)$ \\
Ethnicity & & $95 \%$ CI & $95 \% \mathrm{CI}$ & $95 \% \mathrm{CI}$ & $95 \% \mathrm{CI}$ \\
\hline White & 147 & $143.44(15.56)$ & $61.38(6.88)$ & $3.26(0.35)$ & $3.23(0.44)$ \\
& & {$[140.91,145.98\rceil$} & {$[60.25,62.50]$} & {$[3.20,3.31]$} & {$[3.16,3.31]$} \\
\hline Total & 733 & $144.68(18.18)$ & $61.76(6.94)$ & $3.22(0.37)$ & $3.17(0.43)$ \\
& & {$[143.36,145.99]$} & {$[61.26,62.27\rceil$} & {$[3.19,3.24]$} & {$[3.14,3.20]$} \\
\hline
\end{tabular}

Note. $\mathrm{CI}=$ confidence interval. ${ }^{*} p<.05$, Significant difference between Other and Asian for SJSU cumulative units; *Significant difference between Hispanic compared to Asian and White for cumulative GPA, Significant difference between Hispanic compared to Asian, White, and Other for SJSU cumulative GPA.

This study used quantitative analysis to examine the preliminary outcomes of the AS-T in Business Administration program at San José State University. Specifically, this study revealed that AS-T earners do not earn their baccalaureate degree within 2-years of transfer. A second research question compared how AS-T in business administration earners and non-AS-T in business administration earners fare at degree completion and hypothesis testing indicate AS-T students earn fewer SJSU units than non-AST students. In addition, this study found the nature of several associations between categorical variables. Lastly, this study showcased the differences between URM and non-URM students. The following chapter will offer discussion and implications for leadership, practice and equity. 


\section{Chapter Five: Discussion and Implications}

This chapter will include three sections. First, a summary of the major findings associated with the AS-T program and their significance are presented. As appropriate, connections to previous research and the research framework will also be made. The second section will address the limitations of this study and recommendations for future research. The last section will offer implications for leadership, practice and equity.

\section{Summary of Major Findings and Conclusions}

The evidence from this study indicate a few major findings. First, AS-T earners do not earn their baccalaureate degree within two years of transfer. In addition, when AS-T earners are compared to non-AS-T earner sub-groups, such as, Associate of Arts/Science earners and students without an associate degree, the time (years/terms) to degree completion for AS-T earners is not statistically significantly different. When examining time (years/terms) to degree, on average, the URM group was statistically significantly higher compared to the non-URM group. When the URM group was disaggregated, the number of years to time to degree by specific race and ethnicity, on average was statistically significantly higher for Asian students when compared to White students. In addition, there was no statistically significant difference between Hispanic and White students. Second, in terms of units earned, AS-T students earn on average, three SJSU cumulative units less when compared to transfer students without an associate degree. In addition, the cumulative units earned, on average, was statistically 
significantly higher for transfer students with an AA degree when compared to transfers students without an associate degree. Lastly, there was one significant association worth noting. Students with an AS-T were overrepresented in the ethnic categories of Other and Hispanic, and underrepresented in the Asian student population.

The evidence from this research study offers mixed conclusions about the preliminary outcomes of the AS-T program in business administration. First, students with an AS-T are intended to complete their degree within two-years of transfer, but evidence indicates their time to degree completion is greater than two-years. However, on average, the AS-T students earn their degree in less time than non-AS-T students. When examining time (years/terms) to degree by URM versus non-URM, the URM group was statistically significantly higher compared to the non-URM group. This may be because Asians were included in the URM group. In addition, when considering race and ethnicity, Asian students have on average, a statistically significantly higher number of years to degree completion when compared to White students, which could be due to the term in which Asian students complete their degree. That is, as indicated in the characteristics of the sample section found in chapter four, among the fall 2016 cohort, 2 $(0.2 \%)$ completed by spring 2017 which are denoted as a one-year graduation rate.

Students who earned their degree in two-years, completed their degree in the following terms: $13(1.4 \%)$ by fall $2017,308(32.7 \%)$ by spring 2018 , and $51(5.4 \%)$ by summer 2018. Those that completed their degree in three-years finished their degree in the following terms: $247(26.2 \%)$ by fall 2018 and $112(11.9 \%)$ by spring 2019 . When 
considering how terms are taken into consideration when computing years to graduation, it is probable that more White students finished their degree in the terms preceding fall 2018 and more Asian students completed their degree fall 2018 or later. Lastly, there was no statistically significant difference between Hispanic and White students regarding time to degree completion. Historically, an achievement gap between these groups has persisted, therefore these results suggest the gap has been eliminated in this study. Further research could help identify possible conclusions why this occurred.

A second conclusion, regarding the difference this program is having on the average AS-T earner is they are earning three cumulative SJSU units fewer than their peers and earning about 60 units at SJSU when completing their Bachelor of Science in Business Administration degree. These key findings connect directly to the intent of the AS-T program, which aims to support degree completion in an efficient manner. That is, an AS-T program is intended to reduce the loss of transfer credits and enhance transfer credit applicability by fulfilling lower-division general education, preparation for the major and lower-division major requirements. This finding suggests that AS-T earners had most, if not all, their transfer credit applied to their baccalaureate degree and experienced minimal to no transfer credit loss, which ultimately support degree completion as found in prior research (Doyle, 2006). In some cases, when students finish with three fewer units, this may be the difference of paying part-time (1.0 to 6.0 units) tuition at $\$ 2,720$ or full-time (6.1 or more units) tuition at $\$ 3,926$. For a campus that awards $\$ 425$ million in financial aid to eligible students, this could be saving students 
over $\$ 1,000$. The review of relevant policy publications and reports indicate that the number of transfer students with an $\mathrm{AD}-\mathrm{T}$ continue to increase and this study showed that $208(21.1 \%)$ of the fall 2016 transfer cohort earned an AS-T degree, compared to 138 (14.7\%) that earned an AA degree. This key finding is a preliminary indication the AS-T program is slowly becoming the associate degree program of choice for aspiring transfers.

Another conclusion related to units earned is regarding the number of cumulative units earned by the fall 2016 cohort. Since the evidence indicated, the number of cumulative units earned, on average, was statistically significantly higher for transfer students with an AA degree when compared to transfers students without an associate degree. This finding may be interpreted in the following manner. California community college students may have begun their undergraduate experience with the intention of earning a traditional associates degree and then later, became inspired to transfer and earn their baccalaureate degree. Because the traditional AA/AS degree requirements do not align with all CSU admission requirements and lower-division major requirements, these students would need to earn more units prior to transfer to complete their associate degree requirements and the CSU admission requirements. As a result, they would have more cumulative units earned than students without an associate degree. On the other hand, the transfer students without an associate degree, may be among the savviest of aspiring transfer students, who know their initial goal is to transfer and do not prioritize earning any type of associate degree. Therefore, it seems reasonable that these transfer students, 
would on average, earn fewer units than transfer students with a traditional associate degree.

Lastly, students with an AS-T were overrepresented in the ethnic categories of Other and Hispanic, and underrepresented in the Asian student population. This finding is unclear and could be interpreted better with a study that included a qualitative approach. In-depth interviews or focus groups could provide additional information to help interpret this significant finding. Since SJSU is an AANAPISI, targeted communication to the Asian student population about the benefits of the AS-T program is needed and a qualitative component to future research could provide a more nuanced approach to an effective marketing campaign.

\section{Study Limitations and Recommendations}

The quantitative methodology used for this study provided findings that addressed the proposed research questions. However, there are some limitations to this study. The first limitation is the absence of the fall 2015 cohort. In early consultations with the Director of Institutional Effectiveness and Analytics at San José State University, from which the data set was requested, it was anticipated that the data from the fall 2015 cohort was reliable. However, after the official request for student records was made, it became apparent to the Director upon assembling the data set, that the data from the fall 2015 cohort was unreliable for the key independent variable, Associate Degree for Transfer. In which case, the research study needed to eliminate this cohort. The 
inclusion of a second cohort, in particular, an earlier cohort, would have provided a longitudinal component to the findings of this study. Since most transfer students finish in three-years after transfer, comparing the fall 2015 cohort to the fall 2016 cohort would offer an option to identify variable patterns over time and add strength to this crosssectional study.

There are two other limitations that are important to address. The first is the limitation of self-selection. Transfer students self-selected to obtain an AD-T prior to transfer, which introduces a degree of self-selection bias. However, since the transfer students in the fall 2016 cohort were not assigned to the AS-T program group nor the comparison group, these groups are considered naturally occurring. In addition, there are also variables that may influence aspiring transfer students that were not taken into consideration for this study. These influencing factors are variables that are unobservable such as, motivation, resilience and commitment to earn a baccalaureate degree.

Therefore, these unobservable variables were not measured nor considered in a specific way.

Lastly, the addition of a qualitative component to this study could help interpret the research findings. The three specific findings where more information could be used are regarding time to degree, SJSU cumulative units earned, and the underrepresentation of Asian students with an AS-T degree. Conducting a few focus groups that are designed to interact with transfer students and solicit more information about these topics could be 
fruitful. The focus groups would prioritize the composition of students by degree type such as AD-T, Associate degree, and no associate degree type, which would allow for a certain level of homogeneity based on degree type. However, the heterogeneity among each group would aim to have representation of students that include demographics, such as concentration, racial/ethnic background and completion year/term. An opportunity to listen to students' perspectives and experiences as they relate to these topics could help interpret these findings.

The following recommendations for further research on this topic are based on the findings of the study. First, this study focused on how AS-T earners compare to non-AST earners at degree complete. Thus, further research could use a mixed methods design, specifically a quantitative to qualitative approach to help interpret findings and give a voice to student's experiences about the AS-T program at the receiving four-year institution. Some qualitative research questions could include: How and when did they learn about the AS-T program? What did they have to do to earn an AS-T in business administration? What influenced them to follow this guided pathway? How did they perceive the benefits of the AS-T program? A second way to further research in this area, could include a multivariate analysis. Variables could include institutional characteristics from feeder community colleges, such as institution type, size, and federal designation such as Asian-American Pacific Islander Serving Institution and Hispanic Serving Institution. Other variables could include demographic variables, such as English as a primary language and one or both parents born in the United States. 
Conducting a multivariate analysis could identify patterns and relationships between several variables simultaneously. A third way to further research in this area is to conduct a multi-institutional study. The Business Administration degree is offered at most CSU campuses and continues to be the most common degree awarded. Therefore, a study that includes a few campuses could help showcase patterns, relationships and outcomes of the AS-T program. This study could showcase the commitment to access and degree completion for California community college transfers to the CSU.

\section{Implications for Leadership, Practice and Equity}

This last section will offer implications for leadership, practice and equity to enhance the implementation of Senate Bill 1440 (2010) and 440 (2013).

\section{Leadership.}

There are two implications for leadership to further support the AS-T program in Business Administration. First, the California Community College system, should promote the AS-T program as the most efficient and clear curriculum for their aspiring transfer students with an interest in completing their baccalaureate degree in Business Administration at a CSU campus. Baccalaureate-aspiring students do not have a clear transfer curriculum. The AS-T program offers aspiring transfer students the benefit of fulfilling all lower-division general education and major requirements prior to transfer and assuring they are academically prepared for upper-division course work in their major. Prior research indicates community college students have too many options, that 
lead to uncertainty (Adelman, 2005). The findings suggest, on average, AS-T students finish their baccalaureate degree within 60 units at SJSU, achieving the AS-T intended outcome and providing a clear and efficient path to a baccalaureate degree. Second, this finding also suggests that the AS-T program is essential for reducing or eliminating the loss of transfer credit for aspiring transfer students. Communication and collaboration between the local CCCs and SJSU are critical to strengthen the vertical transfer pathway from a CCC campus to a CSU campus.

\section{Practice.}

The implications for practice are varied. One, CCCs should consider disaggregating their Asian student population. This would provide the opportunity to target communication to specific Asian communities and ensure they are aware of the AS-T program. A finding in this study, indicates Asian students are underrepresented in the AS-T program. Given the benefits of the program, it is imperative that all Asian students aspiring to transfer are encouraged and offered support to complete an AS-T program. At SJSU, an Asian American, Native American, Pacific Islander Serving Institution, disaggregating the Asian student demographic variable into subgroups should be a common practice. This would allow researchers to understand which Asian communities, for instance, Vietnamese or Pilipino, given the heterogeneity within the Asian community. Statistical analysis using disaggregate date could offer more nuanced results and opportunities for more in-depth learning. As referenced in the research framework, racial inequities in education continue persist and it is important to use CRT 
to analyze and critique policies and practice in education (Ladson-Billings, 2005).

Second, collaboration among the Admission Office, Office of the Registrar and Undergraduate Programs would showcase to AS-T students how their transfer credit has fulfilled requirements at their prior institution. Third, showcasing the results of this study to $\mathrm{AD}-\mathrm{T}$ champions could provide recognition for the work they have done to implement this policy, as additional resources for implementation are rare. Faculty and staff at both the CCC system and CSU system have been highly involved in the development and implementation of the $\mathrm{AD}-\mathrm{T}$ program, without their efforts students would not have a transfer curriculum that guarantees them a path to a baccalaureate degree. Lastly, academic counselors at the CCCs could implement strategies to encourage students to commit to transfer earlier in their collegiate experience. The earlier CCC students decide their educational goal is to transfer, the sooner they can begin to identify an appropriate AD-T program and establish a clear transfer path.

\section{Equity.}

Many first-generation, low-income, and students of color start their baccalaureate degree courses at their local community college (Hagedorn \& Cepeda, 2004; Handel, 2013; Gandara et al., 2012;). Those with the hope to transfer to a CSU and earn a baccalaureate degree have a clear path to do so, as a result of Senate Bill 1440 (2010) and 440 (2013). These statues are essentially equity-focused to improve transfer from the $\mathrm{CCC}$ to $\mathrm{CSU}$ with the promise of degree completion. The preliminary findings of this study also showcase mixed results on the equity front. Regarding time to degree, Asian 
students have on average, a statistically significantly higher number of years to degree completion when compared to White students, but there was no statistically significant difference between Hispanic and White students. These results showcase a clear discrepancy, and the need to ensure SJSU is both Asian-American Native American Pacific Islander Serving Institution and a Hispanic Serving Institution. As the state of California continues to need a more educated workforce, the CCC system and CSU system need to ensure that the $\mathrm{AD}-\mathrm{T}$ program is an equitable, efficient and effective transfer pathway.

Recently, the CCC began to offer free college tuition for the first two-years of college. This past summer, CSU campuses saw a lower yield for their first-time freshmen fall 2019 cohort. This opportunity has redirected many freshmen to the CCC systems. As more freshmen choose to begin their post-secondary education at a CCC, the need to ensure the AD-T program serves as a direct on-ramp to a baccalaureate degree for CCC students aspiring to transfer is important as the future college students will come from historically underserved communities - first in their families to attend college, from low income households and from ethnic groups such as Latinos, African Americans and Southeast Asians. A direct and clear path for these students, their families and communities are essential for racial equity in baccalaureate degree completion.

As stated in chapter one, California Community Colleges have several missions, but the one related to this study is the mission to prepare and support students to transfer 
to a baccalaureate granting institution. Many of the students attending the largest community college system in the United States, are students of color, first-generation college goers and students from low-income households. To improve the transfer mission, the State of California policy makers focused on strengthening the vertical transfer from a Califomia Community College system to the California State University system, by way of Senate Bill 1440 (2010) and 440 (2013). This legislation is essentially an equity-focused policy to support baccalaureate degree attainment for historically underserved students. Using a research framework, this study analyzed the outcomes of the Associate Degree for Transfer (AD-T) program, specifically the Associate of Science for Transfer in Business Administration at San José State University. Chapter two, defined the various types of transfer students and the need to improve vertical transfer from a community college to a four-year institution. Prior research identified challenges aspiring transfer students face at the community college (sending institution) and the four-year institution (receiving institution). A search for relevant education policy publications and reports showcased an overview of the $\mathrm{AD}-\mathrm{T}$ program at the California Community College system and California State University system. In addition, material on the traditional Associate of Arts or Science degree in Business Administration, Associate of Science for Transfer in Business Administration at a CCC, and the Associate of Science for Transfer in Business Administration at San José State University, provided a description of each degree and a clear understanding of the intended objectives. Chapter three stated the rationale to use a quantitative methodology to answer the 
proposed research questions and the data collection methods and statistical analysis performed for this study. Chapter four revealed the key findings and data generated per the statistical methods used to address each research question.

This chapter offered a summary of the major findings associated with the AS-T program and their significance. As appropriate, connections to previous research were made. The second section addressed the limitations of this study and recommendations for future research using a mixed methods approach. The chapter concluded with implications for leadership, practice and equity as they relate to the preliminary findings of the AS-T in Business Administration at SJSU, one of the most diverse institutions in United States. 


\section{Bibliography}

Adelman, C. (2005). Moving into town - and moving on: The community college in the lives of traditional-age students. Retrieved from U.S. Department of Education website: https://www.ed.gov/

Bahr, P. R. (2008). Does mathematics remediation work?: A comparative analysis of academic attainment among community college students. Research in Higher Education, 49, 420-450. doi: 10.1007/s1162-008-9089-4

Bailey, T., \& Morest, V.S. (2006). Introduction: Defending the community college equity agenda. In T. Bailey \& V.S. Morest (Eds.), Defending the community college equity agenda (pp. 1-27). Baltimore, MD: John Hopkins University Press.

Bowen, W.G., Chingos, M.M., \& McPherson, M.S. (2009). Crossing the finish line: Completing college at America's public universities. Princeton, JN: Princeton University Press.

California Community Colleges Chancellor's Office (2012a). Advancing student success in California community colleges: Recommendations of the California community colleges student success task force. Retrieved from http://www.cccco.edu/

California Community Colleges Chancellor's Office (2012b). Basic skills accountability supplement to the ARCC report. Retrieved from http://www.cccco.edu/ 
California Community Colleges Chancellor's Office (2018a). California community college statewide enrollments. Retrieved from: https://datamart.cccco.edu/Students/Enrollment Status.aspx

California Community Colleges Chancellor's Office (2018b). California community college key facts. Retrieved from:

http://www.californiacommunitycolleges.cccco.edu/PolicvInAction/KevFacts.asp $\underline{\mathrm{x}}$

California Community Colleges Chancellor's Office (2018c). Tools for students - learn about financial aid. Retrieved from:

$\underline{\text { http://californiacommunitycolleges.cccco.edu/Students.aspx }}$

California Community Colleges Chancellor's Office (2019a). Course Identification Numbering System (C-ID). Retrieved from https://www.C-id.net/

California Community Colleges Chancellor's Office (2019b). Data Mart Student Count Annual 2016-2017. Retrieved from https://datamart.cccco.edu/DataMart.aspx California Postsecondary Education Commission (2018). Enrollment fall term transfers to public institutions. Retrieved from http://www.cpec.ca.gov

California State University (2018). CSU undergraduate and graduate degrees granted 2015. Retrieved from http://www.calstate.edu/as/stat reports/2015$\underline{\text { 2016/degree1516.shtml }}$ 
Chavez, L. (2008). Untapped potential: Latinos and Calfornia community colleges. Retrieved from University of California, Berkeley, Center for Latino Policy Research website: $\underline{\text { http://clpr.berkelev.edu/ }}$

Crisp, G., \& Nuñez, A.M (2014). Understanding the racial transfer gap: Modeling underrepresented minority and nonminority students' pathways from two-to fouryear institutions. The Review of Higher Education, 37, 291-320. doi:

10.1353/rhe.2014.0017

Dougherty, K.J. (1992). Community colleges and baccalaureate attainment. Journal of Higher Education, 63(2), 188-214.

Dougherty, K.J., \& Kienzl, G.S. (2006). It's not enough to get through the open door: Inequalities by social background in transfer from community colleges to fouryear colleges. Teachers College Record, 108(3), 452-487.

Doyle, W.R. (2006). Community college transfers and college graduation: Whose choices matter most? Change: The Magazine of Higher Learning, 38, 56-58. doi: $10.3200 /$ chng.38.3.56-58

Driscoll, A. K. (2007). Beyond access: How the first semester matters for community college students' aspirations and persistence (Research Report No. 07-2). Retrieved from Policy Analysis for California Education website: https://edpolicvinca.org/

Fowler, F.C. (2013). Policy studies for education leaders: An introduction (4th ed.). Upper Saddle River, NJ: Pearson Education. 
Gandara, P., Alvarado, E., Driscoll, A., \& Orfield, G. (2012). Building pathways to transfer: Community colleges that break the chain of failure for students of color. Retrieved from UCLA, The Civil Rights Project/Proyecto Derechos Civiles website: http://www.civilrightsproiect.ucla.edu

Geiser, S., \& Atkinson, R. C. (2010). Beyond the master plan: The case for restructuring baccalaureate education in California (CSHE. 16.10). Retrieved from UC Berkeley, Center for Studies in Higher Education website: httos://cshe.berkelev.edu/

Glass Jr, J.C., \& Harrington, A.R. (2002). Academic performance of community college transfer students and native students at a large state university. Community College Journal of Research and Practice, 26, 415-430. doi: $10.1080 / 02776770290041774$

Goldrick-Rab, S. (2007). Promoting academic momentum at community colleges: Challenges and opportunities (CCRC Working Paper No. 5). Retrieved from Columbia University, Community College Research Center website: https://ccrc.tc.columbia.edu/

Hagedorn, L., \& Cepeda, R. (2004). Serving Los Angeles: Urban community colleges and educational success among Latino students. Community College Journal of Research and Practice, 28(3), 199-211.

Hagedorn, L.S., Moon, H.S., Cypers, S., Maxwell, W.E., \& Lester, J. (2006). Transfer between community colleges and 4-year colleges: The all-american game. 
Community College Journal of Research and Practice, 30, 223-242. doi:10.1080/10668920500322384

Hills, J.R. (1965). Transfer shock: The academic performance of the junior college transfer. The Journal of Experimental Education, 33(3), 201-215.

Handel, S.J. (2011). Increasing higher education access and success using new pathways to the baccalaureate: The emergence of a transfer-affirming culture (December 2011). Retrieved from College Board https://www.collegeboard.org/

Handel, S.J. (2013). The transfer moment: The pivotal partnership between community colleges and four-year institutions in securing the nation's college completion agenda. New Directions for Higher Education, 162, 5-15. doi: 10.1002/he.20052

Hodara, M., Martinez-Wenzl, M., Stevens, D., \& Mazzeo, C. (2016). Improving credit mobility for community college transfer students: Findings and recommendations from a 10-state study. Planning for Higher Education, 45(1), 50-116.

Horn, L. (2009). On Track to Complete? A Taxonomy of Beginning Community College Students and Their Outcomes 3 Years After Enrolling: 2003-04 Through 2006 (NCES 2009-152). Retrieved from U.S. Department of Education, National Center for Education Statistics website: https://nces.ed.gov/ Hossler, D., Shapiro, D., Dundar, A., Ziskin, M., Chen, J., Zerquera, D., \& Torres, V. (2012). Transfer \& mobility: A national view of pre-degree student movement in postsecondary institutions (Signature Report No. 2). Retrieved from Indiana University, Center for Postsecondary Research, Project on Academic Success 
website: http://pas.indiana.edu/pdf/transfer\%20\&\%20mobility.pdf

Johnson, H. (2009). Educating Calffornia: Choices for the future. Retrieved from Public Policy Institute of California website: http://www.ppic.org

Johnson, H., \& Hill, L. (2015). Population: Growth will put pressure on infrastructure. Retrieved from Public Policy Institute of California website: http://www.ppic.org Kadlec, A., \& Gupta, J. (2014). Indian regional transfer study: The student experience of transfer pathways between ivy tech community college and indiana university. Retrieved from Public Agenda website: https://www.publicagenda.org/reports/indiana-regional-transfer-studv/

Kirk-Kuwaye, C., \& Kirk-Kuwaye, M. (2007). A study of engagement patterns of lateral and vertical transfer students during their first semester at a public research university. Journal of The First-Year Experience \& Students in Transition, 19(2), 9-27.

Laanan, F.S. (1996). Making the transition: Understanding the adjustment process of community college transfer students. Community College Review, 23(4), 69-84.

Laanan, F.S. (2007). Studying transfer students: Part II: Dimensions of transfer students' adjustment. Community College Journal of Research and Practice, 31, 37-59. doi:10.1080/10668920600859947

Ladson-Billings, G., \& Tate, W.F. (1995). Toward a critical race theory of education. Teachers College Record, 97, 47-68. 
Ladson-Billings, G. (2005). The evolving role of critical race theory in educational scholarship. Race Ethnicity and Education, 8, 115-119. doi:

$10.1080 / 1361332052000341024$

Marshall, C. (Ed.). (1997). Feminist critical policy analysis: A perspective from postsecondary education. London, UK: Falmer Press.

Melguizo, T., Hagedorn, L.S., \& Cypers S. (2008). Remedial/developmental education and the cost of community college transfer: A Los Angeles county sample. The Review of Higher Education, 31(4), 401-431.

Melguizo, T., Kienzl, G.S., \& Alfonso, M. (2011). Comparing the educational attainment of community college transfer students and four-year college rising juniors using propensity score matching methods. The Journal of Higher Education, 82, 265291. doi: https://doi.org/10.1353/jhe.2011.0013

Monaghan, D.B., \& Attewell, P. (2015). The community college route to the bachelor's degree. Educational Evaluation and Policy Analysis, 37, 70-91. doi:10.3102/0162373714521865

Moore, C., Shulock, N., \& Jensen, C. (2009). Crafting a student-centered transfer process in California: Lessons from other states. Retrieved from California State University, Sacramento, Institute for Higher Education Leadership \& Policy $\underline{\text { http://www.csus.edu/ihelp }}$

Moore, C., \& Shulock, N. (2007). Beyond the open door: Increasing student success in the California community colleges. Retrieved from California State University, 
Sacramento, Institute for Higher Education Leadership \& Policy http://www.csus.edu/ihelp

Moore, C., \& Shulock, N. (2010). Divided we fall: Improving completion and closing racial gaps in California's community colleges. Retrieved from California State University, Sacramento, Institute for Higher Education Leadership \& Policy http://www.csus.edu/ihelp

Murray, V.E. (2008). The high price of failure in California: How inadequate education costs schools, students and society. Retrieved from Pacific Research Institute website: http://www.pacificresearch.org

Offenstein, J., \& Shulock, N. (2009). Technical difficulties: Meeting California's workforce needs in science, technology, engineering, and math (STEM) fields. Retrieved from California State University, Sacramento, Institute for Higher Education Leadership \& Policy website: http://www.csus.edu/ihelp

Ornelas A., \& Solorzano, D.G. (2004). Transfer conditions of latina/o community college students: A single institution case study. Community College Journal of Research and Practice, 28, 233-248. doi: 10.1080/10668920490256417

Perez, A. P., \& Ceja, M. (2010). Building a Latina/o student transfer culture: Best practices and outcomes in transfer to universities. Journal of Hispanic Higher Education, 9, 6-21. doi:10.1177/1538192709350073

Reed, D. (2008). California's future workforce: Will there be enough college graduates? Retrieved from Public Policy Institute of California http://www.ppic.org/. 
Rendon, L.I., \& Valadez, J.R. (1993). Qualitative indicators of hispanic student transfer. Community College Review, 20(4), 27-37

San José State University, (2018a). Student Quick Facts. Office of Institutional Effectiveness \& Analytics. Retrieved from http://www.iea.sisu.edu/

San José State University, (2018b). Student Success Milestones. Office of Institutional Effectiveness \& Analytics. Retrieved from http://www.iea.sisu.edu/

Shapiro, D., Dundar, A., Huie, F., Wakhungu, P.K., Yuan, X., Nathan, A. \& Hwang, Y. (2017). Tracking transfer: Measures of effectiveness in helping community college students to complete bachelor's degrees (Signature Report No. 13). Retrieved from National Student Clearinghouse Research Center website: https://nscresearchcenter.org/

Simone, S.A. (2014). Transferability of postsecondary credit following student transfer or coenrollment (NCES 2014-163). Retrieved from U.S. Department of Education, National Center for Education Statistics website: http://nces.ed.gov/pubsearch

Solorzano, D.G., \& Yosso, T.J. (2001). Critical race and latcrit theory and method: counter-storytelling chicana and chicano graduate school experiences. International Journal of Qualitative Studies in Education, 14, 471-495. doi: $10.1080 / 09518390110063365$ 
Stern, J.M.B., (2016). The effect of articulation agreements on community college transfers and bachelor's degree attainment. Community College Journal of Research and Practice, 40, 355-369. doi: 10.1080/10668926.2015.1065209

Strother, S., Van Campen, V., Grunow, A. (2013). Community college pathways: 20112012 descriptive report. Retrieved from The Carnegie Foundation for the Advancement of Teaching website: http://www.carnegiefoundation.org

Taylor, M. (2015). Implementation update: Reforming transfer from CCC to CSU. Retrieved from Legislative Analyst's Office website: www.lao.ca.gov Taylor, J.L., \& Dimpal, J. (2017). The multiple dimensions of transfer: Examining the transfer function in american higher education. Community College Review, 45, 273-293. doi: $10.1177 / 0091522117725177$

The Campaign for College Opportunity. (2016, March). Keeping the promise: Going the distance on transfer reform. Retrieved from The Campaign for College Opportunity website: www.collegecampaign.org

Townsend, B.K. (2001). Redefining the community college transfer mission. Community College Review, 28(2), 29-42.

Townsend, B.K., \& Wilson, K.B. (2009). The academic and social integration of persisting community college transfer students. Journal of College Student Retention, 10, 405-423. doi: 10.2190/CS.10.4.a 
Wang, X. (2008). Baccalaureate attainment and college persistence of community college transfer students at four-year institutions. Research in Higher Education, 50, 570588. doi: $10.1007 / \mathrm{s} 11162-009-9133-\mathrm{z}$

Wassmer, R., Moore, C., \& Shulock, N. (2004). Effect of racial/ethnic composition on transfer rates in community colleges: Implications for policy and practice. Research in Higher Education, 45(6), 651-672.

Warren, J.R., Sheridan, J.T., \& Hauser, R.M. (2002). Occupational stratification across the life course: Evidence from the Wisconsin longitudinal study. American Sociological Review, 67, 432-455. doi: 10.2307/3088965

Yosso, T.J. (2005). Whose culture has capital? A critical race theory discussion of community cultural wealth. Race Ethnicity and Education, 8, 69-91. doi: $10.1080 / 1361332052000341006$

Young, M.R. (1999). Multifocal educational policy research: Toward a method for enhancing traditional educational policy studies. American Educational Research, 36(4), 677-714. 


\section{Appendix: Operational Definitions}

The terms below have been operationalized for this study.

\section{Associates Degree for Transfer (AD-T) Program}

Students attending a California Community College are eligible to earn an Associate Degree for Transfer (AD-T) when they earn 60 semester or 90 quarter units, consisting of general education courses and courses in an academic major. When students complete the $\mathrm{AD}-\mathrm{T}$ they receive guaranteed priority admissions to a $\mathrm{CSU}$ campus and into a program similar to the associate degree earned at a California Community College. AD-T students are not guaranteed admission into a specific campus or major program. There are two types of AD-T programs: Associate in Arts for Transfer (AA-T) and Associate in Science for Transfer (AS-T).

https://www2.calstate.edu/applv/transfer/pages/ccc-associate-degree-for-transfer.aspx

\section{Associate of Science for Transfer (AS-T)}

The Associate of Science for Transfer (AS-T) degrees include a variety of programs such as Agriculture Animal Science, Business Administration, Computer Science, Kinesiology, and Nutrition. http://adegreewithaguarantee.com/

\section{Bachelor of Science in Business Administration at SJSU}

San José State University offers a Bachelor of Science in Business Administration in 13 concentrations which include: Accounting, Accounting Information Systems, Business Analytics, Corporate Accounting \& Finance, Entrepreneurship, Finance, 
General Business, Global Operations Management, Human Resource Management, International Business, Management, Management Information Systems, and Marketing.

\section{AS-T in Business Administration at California Community Colleges}

Per the CCC-CSU Transfer Model Curriculum, the AS-T in Business

Administration is designed for $\mathrm{CCC}$ students that major in Business Administration and wish to pursue the same or similar degree at a CSU campus. The AS-T in Business Administration requires a minimum of 23 units, that includes five courses (financial accounting, managerial accounting, principles of microeconomics, principles of macroeconomics, and business law or legal environment of business), one quantitative reasoning course (business calculus, statistics, or finite mathematics), and two of the following: an additional quantitative reasoning course, business information systems/computer skills, or introduction to business/business communication (https://www.c-id.net/tmc).

\section{AS-T in Business Administration at SJSU}

As of fall 2015, San José State University offered seven AS-T in Business Administration degrees in the following concentrations: Business Analytics, Entrepreneurship, Finance, General Business, Global Operations Management, Human Resource Management and Management. http://www.sisu.edu/gup/ugs/SB1440/ 


\section{Upper-Division Transfer Students from a California Community College}

Students who attend and earn most of their 60 transferable semester units (from a California Community College) and were admitted as an upper-division transfer (Junior Standing) to San José State University.

$\underline{\text { http://www.sisu.edu/transferadmissions/admission-requirements/index.html }}$ 